CAHIER DE RECHERCHE \#2002E

Département de science économique

Faculté des sciences sociales

Université d'Ottawa
WORKING PAPER \#2002E

Department of Economics

Faculty of Social Sciences

University of Ottawa

\title{
Ancestral Norms, Legal Origins, and Female Empowerment
}

\author{
Abel Brodeur ${ }^{*}$, Marie Christelle Mabeu ${ }^{\dagger}$, and Roland Pongou ${ }^{\ddagger}$
}

March 2020

\footnotetext{
* Department of Economics, University of Ottawa, 120 University Private, Ottawa, Ontario, Canada, K1N 6N5; email: abrodeur@uottawa.ca.

† Department of Economics, University of Ottawa, 120 University Private, Ottawa, Ontario, Canada, K1N 6N5; email: mmabe017@uottawa.ca.

‡ Department of Economics, University of Ottawa, 120 University Private, Ottawa, Ontario, Canada, K1N 6N5; email: rpongou@uottawa.ca.
} 


\begin{abstract}
A large literature documents persistent impacts of formal historical institutions. However, very little is known about how these institutions interact with ancestral traditions to determine long-term economic and social outcomes. This paper addresses this question by studying the persistent effect of legal origins on female economic empowerment in sub-Saharan Africa, and how ancestral cultural norms of gender roles may attenuate or exacerbate this effect. Taking advantage of the arbitrary division of ancestral ethnic homelands across countries with different legal origins, we directly compare women among the same ethnic group living in civil law countries and common law countries. We find that, on average, women in common law countries are significantly more educated, are more likely to work in the professional sector, and are less likely to marry at young age. However, these effects are either absent or significantly lower in settings where ancestral cultural norms do not promote women's rights and empowerment. In particular, we find little effect in bride price societies, patrilocal societies, and societies where women were not involved in agriculture in the past. Our findings imply that to be optimal, the design of formal institutions should account for ancestral traditions.
\end{abstract}

Key words: Legal Origins, Ancestral Norms, Women's Empowerment, Gender Roles.

JEL Classification: D03, I25, J16, N37. 


\section{Introduction}

A large body of work shows that legal institutions have important effects on economic and social outcomes (La Porta et al. (2008)). At the same time, it is argued that the effect of legal institutions might depend on the cultural and traditional contexts in which these institutions are implemented (Alesina and Giuliano (2015); Bisin and Verdier (2017); Nunn (2012)). However, we continue to have a very limited understanding of particular cultural contexts that affect the efficacy of legal institutions. Such an understanding is important for the optimal design of institutions.

In this paper, we analyze the interaction of legal origins and ancestral cultural norms on gender roles in determining female economic empowerment in sub-Saharan Africa. Sub-Saharan Africa is an ideal setting for studying this question because women's rights and economic opportunities are severely limited in this region. Indeed, the plight of African women is of utmost concern. As of 2012, only 75 percent of primary school-aged girls attended school and secondary gross enrolment ratios were lower than 40 percent. Only 64 percent of young women were literate in comparison to 76 percent for young men. About two-fifths of sub-Saharan African women were married before age 18, and experience of sexual violence for these women is the highest in the world (United Nations (2015)).

Legal traditions, and their interaction with ancestral or traditional norms, may have profound effects on women. A large literature argues that the common law system generates more economic opportunities than the civil law, and promotes institutions that foster economic development (e.g., La Porta et al. (1999); North (1989)). The common law system is characterized by greater independence of the judicial system, lower government ownership, and stronger legal protection of investors (e.g., Beck et al. (2003)). These features are known to reduce the risk of expropriation and to promote contract enforcement and secured property rights, resulting in more investment and economic growth in common law countries compared to civil law countries. It follows that the common law system is likely to reduce the (relative) cost of human capital investment through affecting both the supply of, and the returns to, education.

To formally understand how legal origins may interact with traditional norms, we develop a very simple model in which parents decide on the quantity and quality of children. The relative price of human capital depends on legal origins and the utility-weight assigned to child quality is a function of traditional norms. The key prediction of the model is that a lower cost of human capital is associated with greater investment in human capital, but this relationship is more pronounced in societies where traditional norms assign greater utility to child quality. In other words, compared to the civil law system, the common law system better promotes female education (and economic empowerment), and this positive effect is greater in societies where ancestral norms of gender roles pro- 
mote women more. In addition, to the extent that the promotion of women's rights is antithetical to that of men's rights, our model directly predicts that, although the common law system may also positively affect male education, this positive effect should be less pronounced in societies where traditions promote women's rights.

To provide direct empirical evidence for the effect of legal origins on female economic empowerment in sub-Saharan Africa and how this effect depends on traditional norms of gender roles, we follow the approach of Michalopoulos and Papaioannou (2014) and exploit the fact that colonists partitioned several ethnic groups into adjacent countries with different formal institutions (Michalopoulos and Papaioannou (2016)). More precisely, we exploit the exogenous variation in legal origins across countries and directly compare women among the same ethnic group living in civil law countries and common law countries. Using this spatial Regression Discontinuity Design (RDD), we show that women in common law countries have about two years of education more than women in civil law countries. This "average" effect is large as the mean years of education in our sample is 3.12. This result is exactly the relationships our theory predicts. One potential issue is that women in civil law countries are more likely to have higher grade repetition rates, which could lead to higher dropout rates (Dupraz (2019)). We tackle this issue by analyzing the impact of legal origins on other educational outcomes. Our RDD estimates suggest that women in common law countries are approximately 20 percentage points more likely to have at least one year of education, suggesting that our findings are not entirely driven by higher grade repetition rates in civil law countries. Similarly, women in common law countries are significantly more likely to have completed primary and secondary school by 7 and 2 percentage points, respectively.

Consistent with this positive average effect of common law on female education, our RDD estimates also show that women in common law countries are significantly more likely to work in the professional sector (e.g. managerial position, clerical) and they are significantly less likely to marry before age 18 .

Turning to the central part of this paper, we investigate how the effect of legal origins on female outcomes depends on ancestral cultural norms of gender roles. We consider three classical norms arising from ancestral mode of subsistence and marriage traditions: (1) female participation in agriculture, (2) bride price payment, and (3) post-marital residence rules (patrilocality vs. matrilocality). ${ }^{1}$ We validate the prediction that the positive effect of the common law system on female education (and economic empowerment) is lower in settings where cultural norms do not traditionally promote women's rights and empowerment. More precisely, we find that the positive effect of the common law system on female education is lower in societies where women were not allowed to participate in agricultural activities, in societies that practise bride price, and in patrilocal societies. We

\footnotetext{
${ }^{1}$ Patrilocality refers to a post-marital residence norm where the newly-wed couple lives with or near the husband's family. In contrast, in matrilocal societies, the couple lives with the wife's family.
} 
find similar heterogeneous effects of the common law system on female employment, early marriage, and the husband-wife age gap. Interestingly, while the common law system has a negative effect on the husband-wife age gap in societies that traditionally promote women, its effect is positive and significant in societies where women's rights are limited. In addition to these main results, we examine the heterogeneous effect of common law on male education, finding that it has a positive effect that is significantly lower in societies where ancestral traditions promote women's rights and economic empowerment. All of these findings imply that the long-term impact of legal origins varies within the same country as a function of ancestral traditions. They strongly suggest that, to be optimal, the design of formal institutions should take into account the cultural and traditional context in which they will be implemented.

Our paper contributes to a literature on the historical determinants of gender roles and women's outcomes. Previous studies have analyzed the importance of traditional agricultural practices (e.g., Alesina et al. (2013); Hansen et al. (2015)), intergenerational transmission of values (e.g., Fernández et al. (2004)), disequilibria in sex ratios (e.g., Teso (2019)), medical improvements (e.g., Albanesi and Olivetti (2016)), and colonial population policies (Canning et al. (2020)). In a recent study, Anderson (2018) documents that female HIV rates are significantly higher in common law sub-Saharan African countries in comparison to civil law countries. This paper explains this relationship by focusing on differences in female property rights under the two codes of law. ${ }^{2}$ The literature has so far not examined the interplay between historical formal institutions and cultural traditions. Our main contribution is to show that legal origins significantly interact with ancestral norms of gender roles to determine present-day women's economic empowerment.

We also view our analysis as complementing a recent study examining interactions between a contemporary policy reform and traditional norms of gender roles. Ashraf et al. (2020) show that a particular development policy intervention consisting of a school construction program in India and Zambia increased female education only in bride price societies. We find instead that the positive effect of the common law system on female education (and other outcomes measuring women's economic empowerment) has a greater effect in societies that traditionally promote women's rights, including non-bride-price societies. The difference between our findings might be explained by the fact that Ashraf et al. (2020) focus on a one-time policy intervention that was implemented within a relatively short time period, whereas we focus on historical legal institutions, which are more lasting and which, in addition to affecting the supply of education like a school construction program, have other functions like affecting the returns to education. Another novelty of our study is that we also consider male education and show that it is

\footnotetext{
${ }^{2}$ Interestingly, our findings on the "average" effect of common law on early marriage can be viewed as providing another mechanism through which this legal system affects HIV rates. Indeed, marriage delay may increase exposure to risky sexual interactions with non-marital partners, increasing the likelihood of HIV infection.
} 
positively affected by the common law system, but that this positive effect is less visible in societies where ancestral traditions promote women's rights. Our findings seem to suggest that traditions of gender norms directly oppose women's rights to men's rights, and this incompatibility interacts with formal institutions in a non-trivial way. They imply that institutional interventions designed to promote women's economic empowerment in societies where their rights are traditionally constrained should engage men and obtain their support and cooperation.

The remainder of this paper is structured as follows. In section 2, we present our conceptual framework. Section 3 details the data sets and provides descriptive statistics. Section 4 presents the methodology and the model specifications. Section 5 presents estimates of the relationship between legal origins and female outcomes in sub-Saharan Africa. We also show how this relationship depends on ancestral cultural norms of gender roles, which is the central question we address. The last section briefly concludes.

\section{The Theoretical Determinants of Female Human Capital}

\subsection{Legal Institutions: Civil vs Common Law}

A country's legal system encompasses an array of economic policies and institutions that are likely to determine development outcomes. In Africa, the legal system was primarily introduced through colonization and conquest (Watson (1993)) and it varies between common law and civil law colonizers. Typically, former British colonies inherited the British common law system and former European continental colonies (countries colonized by France, Spain, Portugal, Italy and Belgium) retained the roman civil code of laws. In the past two decades, economists have produced a considerable amount of research suggesting that differences in the origin and the ideology of the common and civil legal traditions have generated different institutional arrangements as well as different economic outcomes today (La Porta et al. (1997), La Porta et al. (1998), La Porta et al. (1999), Joireman (2001), Mahoney (2001), Glaeser and Shleifer (2002), La Porta et al. (2008)).

Consistent with Hayek (1973)'s claim of the superiority of English versus French legal traditions in term of several legal outcomes, the economic literature provides strong empirical evidence that common law countries exhibit greater independence of the judicial system, lower government ownership, and stronger legal protection of investors. These features imply that the design of governmental legal institutions in common law countries limits the extent of expropriation and fosters strong legal enforcement of property and contract rights which are associated with greater investment and growth. This is in sharp contrast with the lower level of scrutiny of executive action that characterizes the civil 
law system and which ensures that governments in civil law countries have more scope for alteration of property and contract rights.

The aforementioned structural differences between the two major legal systems in Africa have contributed to explaining the comparative economic development of common and civil law African countries, with the former outperforming the latter in different economic dimensions including education, health, and economic growth (La Porta et al. (1998), Djankov et al. (2002), Glaeser and Shleifer (2002)). By promoting institutions that foster economic development, the common law system generates more economic opportunities with increasing availability of jobs that require education. The common law system could then lead to more female education.

Economists have argued that the rise in female education following economic development can be linked to several economic factors. In particular, it has been shown that as economic development proceeds, the demand for female employment increases. This in turn raises the market return of female education, providing more incentives for investment in girls' education (Pitt et al. (2012), Jayachandran (2015), Heath and Jayachandran (2016)). The rise in female education following economic development could also be driven by the positive impact of economic development on household income. The rationale is, to the extent that parents view girls' education more as a luxury good than boys' education, a positive change in family income will translate into higher spending on girls' education (Heath and Jayachandran (2016)).

As the legal system of a country was introduced by a specific colonizer, it is likely that a country's legal origins correlate with his colonial history (Klerman et al. (2011)). It follows that civil and common law countries could also differ in terms of the colonial strategies implemented by the colonizer. In particular, differences in colonial education policies could directly influence educational outcomes in civil and common law countries. It is well established in the literature that former British colonies outperformed former French colonies in terms of educational outcomes, and this difference has been linked to differences in colonial educational policies (Cogneau and Moradi (2014), Dupraz (2019)). Unlike the French educational strategy, the British educational strategy relied heavily on mission societies to provide and diffuse education. To achieve this goal, the British colonial government highly invested in school infrastructures and provided incentives to missionaries, especially by according grants-to-aid based on the efficiency of the missions' schools (Cogneau and Moradi (2014)). In contrast, the French colonial government barely subsidized mission's schools and made limited investments in school infrastructures. The British-French differences in education policies generate an advantage in educational outcomes in former British colonies. This advantage was especially stronger for females given the greater importance Protestant missions placed on the education of women than Catholic missions (Nunn et al. (2014)). 


\subsection{Ancestral Cultural Norms}

Societies often have rules of social behavior that are based on cultural values and beliefs about women's roles in the society. These values and beliefs mainly originated from pre-industrial socio-economic arrangements. Despite changes in these initial economic conditions, ancestral cultural norms of gender roles have persisted over time, with important socio-economic consequences in the long run. In particular, anthropologists and economists have shown that differences across societies in traditional norms that determine women's socio-economic status can account for contemporary differences in gender related development outcomes (see, for instance, Boserup (1970), Dyson and Moore (1983), Basu (1992, n.d.), Rammohan and Robertson (2012), Alesina et al. (2013), Alesina, Brioschi, and La Ferrara (2016), Lowes and Nunn (2017)). In this paper, we focus on the cultural determinants of gender roles arising from ancestral mode of subsistence and marriage traditions.

\subsubsection{Traditional mode of subsistence}

Social scientists are increasingly emphasizing the role of traditional mode of subsistence in shaping the evolution and persistence of gender roles in the long run. The central idea is that when in past societies, women were highly involved in subsistence activities, their perceived economic value was high, and this in turn fostered the development of social norms in ways that viewed women as productive and more equal to men (Alesina, Brioschi, and La Ferrara (2016)).

As early as 1970, economists examined this claim by primarily focusing on differences in traditional agricultural practices. In a qualitative study, Boserup (1970) distinguished between plough and non-plough (shifting cultivation) agriculture and argued that descendants of ethnic groups that practised plough agriculture have currently less equal beliefs about gender roles. While plough agriculture is capital-intensive and requires more physical strength, shifting cultivation is labor-intensive and relies heavily on the use of hand-held tools such as the hoe or the digging stick for soil preparation. As a result, with male having a physiological comparative advantage in brawn-based activities, plough agriculture led to a division of labor in which men specialized in productive activities outside the home while women specialized in activities in and around the household. It follows that this gender-based division of labor may have led to deeply-held and persistent cultural beliefs that the appropriate role of women is in the domestic sphere, resulting in lower female participation in productive activities outside the household.

Formally, Alesina et al. (2013) empirically test Boserup (1970)'s hypothesis that plough agriculture influences gender division of labor in a way that promotes more unequal gender norms. They compared plough and non-plough agricultural societies from around the world and conclude that ethnic groups that practise plough agriculture are 
characterized by greater gender inequality today. In particular, they found that female descendants of societies that use plough are less likely to participate in the workplace, politics, and entrepreneurial activities.

Analyzing a variety of ancestral modes of production and income generation in the context of Africa, Alesina, Brioschi, and La Ferrara (2016) also find evidence consistent with the idea that societies where women were actively involved in subsistence activities are associated with better female socio-economic outcomes today. They show that in societies that traditionally practise plough agriculture, where as shown in Alesina et al. (2013), women participate less in agriculture, violence against women is higher. They also find similar results for hunting and fishing societies where subsistence activities were mainly dominated by men. In contrast, Alesina, Brioschi, and La Ferrara (2016) find that dependence on agriculture for production and income generation in ancient times, as opposed to hunting, fishing, gathering and pastoralism, is qualitatively associated with a lower level of domestic violence. They argue that, since most African societies were based upon non-plough agriculture ${ }^{3}$, high dependence on agriculture for production and income generation implies that women could participate more in economic activities. Women could therefore develop a more equal status in the society and the family, and this may generate norms of greater gender equality. Taking advantage of Murdock's indicator of female participation in agriculture in past societies (see Section 3 for a detailed description of this variable), we find, consistent with the theory, that in our setting, there is a positive association between female participation in agriculture and female education (see Table A5).

\subsubsection{Marriage Traditions}

Another influential line of research has concentrated on the role of traditional marriage practices in shaping gender roles. In this paper, we focus on two main marriage traditions: marriage payment and post-marital residence rules.

Bride price and dowry are the two most well-known types of marriage payment. The custom of bride price is defined as a cash or in kind transfer from the groom or his family to the bride's family at the time of marriage. In contrast, dowry refers to payment that the bride's parents make to the couple at the time of marriage. Historically, the bride price tradition has been practised throughout African societies, with $83 \%$ of African societies listed in Murdock ethnographic Atlas following a norm of bride price (Murdock (1967)). In recent years, number of anecdotal evidence and descriptive studies have nurtured the debate over the adverse consequences of bride price for girls and women (Hague et al. (2011), Kizito (2013), Mtui (2013)). First, bride price payment is viewed as an abusive practise that play an important role in incentivizing parents to "sell" their daughters early

\footnotetext{
${ }^{3}$ In Alesina, Brioschi, and La Ferrara (2016), 6\% of women's ancestors in the sample traditionally used the plough.
} 
in exchange of a cash or in kind payment. Owing to this perception, some scholars claim that this practise is likely to increase a woman's chance of early marriage, with negative impact on their education and lifetime reproductive health. Second, because bride price payment is associated with a purchase by the groom of the rights to the bride's labor and reproductive ability (Anderson (2007)), it is argued that the custom of bride price leads to the commodification of women with important adverse consequences (Lowes and Nunn (2017)). For instance, to the extent that husbands feel the right to mistreat their wives because they have paid for them (Lowes and Nunn (2017)), bride price tradition is more likely to encourage spousal violence. In addition, the fact that bride price payment induces an explicit economic value for women may also limit their relative independence. A number of scholars have argued in fact that the payment of bride price upon marriage lowers the probability for married women to end or escape an abusive marriage because their parents have to return the bride price back (Ansell (2001)).

Empirically, bride price has been linked to female outcomes in a complex way. Few empirical studies find evidence of the adverse consequences of bride price for girls and women. For instance, focusing on early marriage, Corno and Voena (2016) and Corno et al. (2016) find evidence that a negative shock to family income increases a girl's risk of early marriage in societies that traditionally practise bride price. They conclude that bride price payment obtained upon marriage is used to smooth consumption in the absence of well functioning credit markets. In contrast, many recent empirical studies found either no effect or surprising benefits of bride price traditions for females. On one hand, examining the relationship between bride price amount and variety of outcomes across marriages in Congo, Lowes and Nunn (2017) find no robust evidence that higher bride price is associated with early marriage, higher fertility, or acceptability of domestic violence. On the other hand, Alesina, Brioschi, and La Ferrara (2016) show that female descendants of ethnic group that have bride price traditions are significantly less likely to experience intimate partner violence. In the same vein, Ashraf et al. (2020) focus on female education to demonstrate that ethnic groups that traditionally practise bride price payment upon marriage increased female school enrolment in response to a school construction program in Zambia and Indonesia. They show that within these groups, higher female education at marriage is associated with higher bride price payment received, resulting in greater incentives for parents to invest in girls' education. In our setting however, consistent with Corno and Voena (2016) and Corno et al. (2016), there is a negative correlation between the practise of pride price and female education (see Table A5).

Another marriage tradition that shape gender roles in the society is related to postmarital residence norms which refer to social rules that define the place where a newly-wed couple lives after marriage. Anthropologists commonly distinguish between two types of post-marital residence norms. The patrilocal residence, where the newly-wed couple lives with or near the husband's family or kin; and the matrilocal residence, where the 
couple instead lives with the wife's family. While in our empirical analysis we will oppose these two types of post marital residence it is worth mentioning that anthropologists also recognize the existence of ambilocal residence where the couple can choose either patrilocal or matrilocal residence and the neolocal residence where the couple choose a new residence after marriage.

The anthropological literature on the historical origins of gender roles has typically opposed patrilocal to matrilocal social structures, showing in general that gender differences in parental investment in child quality were more pronounced in patrilocal societies compared to matrilocal societies (Dyson and Moore (1983), Basu (1992, n.d.), Malhotra et al. (1995)). The theoretical explanation is that matrilocal (vs patrilocal) post-marital residence increases parental financial connections with daughters relative to sons, and, therefore, increases parental incentives to invest in their daughters human capital relative to their sons. A growing economic literature has tested this proposition formally. Focusing mainly on India and Indonesia, most empirical studies examining the link between kinship norms and gender inequality in economic outcomes find a negative association between patrilocal exogamy and women's empowerment outcomes including female education, marriage outcomes, and female autonomy (Buttenheim and Nobles (2009), Levine and Kevane (2003), Rammohan and Robertson (2012), Bau (2020)). In the African context, evidence of the relationship between post-marital migration and female empowerment are scarce. Focusing on Indonesia, Ghana, and Mexico, Bau (2020) examines how cultural norms affect parents' human capital investment in their children through strategic channels. She find that patrilocality (vs neolocality)is associated with higher enrolment rates for sons relative to daughters. Similarly, Table A5 shows a negative correlation between patrilocality and female education in our setting.

\subsection{A Simple Model of Interaction Between Legal origins and Culture}

Existing works have widely studied colonial institutions and culture as independent triggers of female human capital formation, in turn adjudicating between the relative importance of each theoretical determinant. In this section, we propose a simple theoretical framework to highlight how institutions that promote women's economic empowerment interact with traditional norms on gender roles to affect parental investment in girls education. The model is very stylized and serves as a motivation for our empirical analysis.

Consider an economy in which an altruistic parent decides on his own consumption, the number of offspring (quantity of children), and the quality of children. As in Galor and Moav (2002), assume that the parent's preferences are represented by the following 
log-linear utility function:

$$
\mathfrak{u}=(1-\pi) \ln \mathrm{c}+\pi\left(\ln \mathfrak{n}+\alpha_{\mathrm{N}} \ln e\right)
$$

where $\mathrm{c}$ refers to non-child consumption goods, $\boldsymbol{n}$ is the total number of living children, and $e$ is the child's level of schooling (quality of children). The exogenous constant parameter $\pi \in(0,1)$ represents parental preferences for children over other forms of consumption goods. The degree of altruism of the representative parent or his/her preferences for child quality is given by $\alpha_{N} \in(0,1)$. Unlike existing models of quantity-quality tradeoff, we allow parental preferences for child quality to vary based on the cultural norm of the ethnic group to which the household belongs. We therefore assume that $\alpha_{N}$ is a function that increases with the extent to which the cultural norm promotes women's human capital and participation in economic activities.

The representative household is endowed with one unit of time. The parent can allocate his/her time between labor market and childrearing activities. If the parent dedicates all his/her time to labor market activities, he/she will generate an income $y$. The time used for childrearing is time away from the labor market and thus represents the opportunity cost of childbearing. There are two costs (in time) associated with childbearing. $\mathrm{K}^{\mathrm{n}}$ is the fraction of the parent's time dedicated to caring for children. $\mathrm{K}^{\mathrm{e}}$ is the time cost for investing in one unit of education. It follows that the parent in this economy faces the following budget constraint:

$$
y n\left(K^{n}+K^{e} e\right)+c=y
$$

Substituting (2) in (1), and solving for the optimization problem leads to the following optimal demand for quality and quantity of children:

$$
\begin{aligned}
& e^{*}=\frac{\alpha_{N}}{1-\alpha_{N}} \frac{K_{n}}{K_{e}} \\
& n^{*}=\frac{\Pi}{K_{n}+K_{e} e}
\end{aligned}
$$

It is straightforward to see that:

$$
\begin{gathered}
\frac{\partial e}{\partial K_{e}}=-\frac{\alpha_{N}}{1-\alpha_{N}} \frac{K_{n}}{K_{e}^{2}}<0 \\
\frac{\partial^{2} e}{\partial K_{e} \partial \alpha_{N}}=-\frac{1}{\left(1-\alpha_{N}\right)^{2}} \frac{K_{n}}{K_{e}^{2}}<0
\end{gathered}
$$

The first comparative static captures the intuition that the parent will invest more in his/her daughter's education when the (relative) price of education decreases. However, the second comparative static implies that when the (relative) price of education 
decreases, education increases less in settings where cultural norms do not promote female empowerment. Based on the literature described above, these comparative statics imply that parents will invest more in female education in the common law system as compared to the civil law system; however, this positive effect of the common law system on female education should be lower in settings where traditions constrain women's rights and empowerment. In summary, these comparative statics lead to the following proposition that we will formally test in Section 5 .

Proposition I: If women are more empowered in societies characterized by higher female participation in agricultural activities, no bride price payment, and matrilocal post-marital norm:

1. The impact of common law on female education will be stronger in societies where women were highly involved in agriculture.

2. The impact of common law on female education will be stronger in societies that do not practise bride price payment.

3. The impact of common law on female education will be stronger in matrilocal societies.

Remark that although we emphasize female education when interpreting the model, it can also be interpreted with a reference to male education. In fact, to the extent that the promotion of women's rights is antithetical to that of men's rights (as in a constant-sum game of rights and resource allocation), our model predicts that the common law system will positively affect male education, but that this positive effect will be less pronounced in societies where traditional norms promote women's rights. Alternatively, the positive effect of the common law system on male education should be greater in societies where ancestral norms do not promote women's rights. Despite the fact that male education is not our main outcome in this paper, we test and validate this hypothesis.

\section{Data and Descriptive Statistics}

To investigate how legal origins interact with ancestral norms of gender roles to shape long-term women's economic empowerment, this paper associates contemporary individuallevel data with ancestral lifeways characteristics of the ethnic group from which they are descended. Our analysis relies on several data sources including the historical data on pre-colonial or ancestral ethnic homelands in Africa with detailed socio-economic characteristics of these groups, the Demographic and Health Surveys from which we obtain measures of women's empowerment outcomes, and other datasets with geographic and ecological variables relevant for our empirical analysis. First we will describe each of these 
datasets and we will highlight the methodology used to link individuals to their ancestral ethnic group. Second we will describe in detail the main variables used in our empirical analysis.

\subsection{Individual-Level Data}

We obtain individual-level information from the Demographic and Health Surveys (DHS). DHS have been conducted in sub-Saharan African countries since 1986. These nationally representative surveys provide reliable information on socio-economic and demographic characteristics of women aged 15 to 49 years. We exploit this set of information to construct our main outcomes of interest.

The central goal in this paper is to compare women's empowerment outcomes across civil and common law countries, and analyze how the effect of legal origins depends on ancestral cultural norms of gender roles. We therefore focus on the DHS conducted in the subset of adjacent countries with different legal origins. ${ }^{4}$ In addition, we only consider DHS waves for which location coordinates of enumeration areas (or villages) are available and for which information on the ethnic identity of the respondent is collected. To ensure full exposure to primary education, we further restrict our analysis to women aged at least 20 years old. This leaves us with 142,301 women living in 19 countries among which 9 are common law countries and 10 are civil law countries (see appendix table A1 for a list of the countries by legal traditions).

\subsection{Ethnicity-Level Data}

Our empirical strategy includes ethnic homeland fixed effects. It is thus necessary to identify historical ethnic homelands that span across countries with different legal origins. We draw information about the spatial location of pre-colonial ethnic homelands in Africa from the George Peter Murdock's Ethnographic Map of Africa (1959). This map portrays the spatial boundaries of 826 ethnic groups across Africa in the eve of the colonial era. Following a similar approach as in Michalopoulos and Papaioannou (2014, 2016) and Anderson (2018), we intersect Murdock's ethnographic map of Africa with the digital chart of the world which portrays contemporary national boundaries in Africa. This allows us to identify 86 ancestral ethnic homelands divided across the set of 19 countries with different legal origins (Figure 1). Using geospatial information of enumeration areas in the DHS, we were able to associate each individual to his/her ancestral ethnic homeland.

Due to migration, relying on the current place of residence may not accurately identify the descendants of each historical ethnic homeland. To address this issue, we exploit the ethnic identity declared in the DHS to link individuals with the ethnic homeland of

\footnotetext{
${ }^{4}$ Data on legal origins come from La Porta et al. (1999).
} 
their ancestors. Given the discordance of ethnicity names available in DHS and Murdock's ethnographic map, we rely on a new system of concordance of ethnic group in Africa to match ethnicities in the DHS with their corresponding ancestral ethnic groups in Murdock's ethnographic map. This system of concordance has been constructed by Michalopoulos et al. (2019). There is a positive correspondence for 41,681 women. Among these women, we restrict our analysis to respondents who are currently living in the homelands of their declared ethnicity. Finally, our empirical analysis is based on a sample of 16,966 women living in 39 ethnic groups partitioned across 7 common law countries and 6 civil law countries.

We augment the final dataset with information on the pre-industrial socio-economic characteristics of historical ethnic groups in Africa. We draw this information from Murdock's Ethnographic Atlas (1967) which is a database of around 60 variables describing the social, economic and political traits of 1270 historical ethnic groups around the world. In this study, we focus on three socio-economic characteristics: (1) female participation in agriculture, (2) bride price tradition, and (3) post-marital residence rules. We provide more details on these variables in the next section.

\subsection{Pixel-Level Data}

To validate our empirical strategy, we provide evidence that legal origins is orthogonal to several geographical characteristics (see Section 4). We measure these geographical characteristics at a very fine level. Following Michalopoulos and Papaioannou (2013), we divide Africa into pixel units of $12 \mathrm{~km} \times 12 \mathrm{~km}$. For each pixel, we rely on different sources (see Section 7) to collect information on the following measures of geographic and natural endowments: elevation, soil suitability for agriculture, area under water (rivers, lakes, streams), natural resources, distance from the centroid of a pixel to the sea coast, and distance from the centroid of a pixel to the national border. In Section 4, we show that civil and common law countries do not systematically differ along these characteristics, which is reassuring as it implies that within each ethnic homeland, areas across the national border with different legal origins are good counterfactuals. Nevertheless, in the empirical analysis in Section 5, we also show regression results controlling for these variables.

\subsection{Descriptive Statistics}

\subsubsection{Dependent Variables}

The first part of Table 1 reports summary statistics for our dependent variables, which include different measures of women's empowerment. Our main outcome of interest is "female education". In our empirical analysis we consider four different indicators measuring 
female education. The first indicator is a continuous variable equal to the total number of years of education declared by the respondent at the time of the survey. The three other measures are three binary indicators for whether the respondent has completed at least one year of schooling, primary education, and secondary education, respectively. Focusing on the first four rows in Table 1 we see that women in our sample have on average 3 years of education. On average, 52\%, 24\%, and 5\% of women have completed at least one year of schooling, primary education, and secondary education, respectively.

Other measures of female economic empowerment that we consider include: female employment and marriage outcomes. First, we measure female employment with a dummy variable indicating whether the respondent is working in the professional sector (e.g. managerial positions or clerical). Table 1 shows that only $3 \%$ of women in our sample are working in the professional sector. Second, we focus on two marriage outcomes. We consider early marriage defined by two dummies indicating if the respondent marry before age 16 or 18 . The second marriage outcome we consider is the partner age gap calculated as the husband-wife age difference. Table 1 shows that $32 \%$ and $56 \%$ of women in our sample marry before age 16 and 18, respectively. In addition, the mean husband-wife age gap is 8 years.

\subsubsection{Ancestral Norms of Gender Roles}

Throughout the analysis in this paper, we will focus on three ancestral cultural characteristics that are measured using Murdock's ethnographic Atlas. The first is "female participation in agriculture". Murdock's Atlas contains detailed information on productive activities prior to industrialization including agricultural activities. In addition, it reports for each productive activity, information about gender differences in participation in this activity. The variable providing information on gender differences in participation in agriculture contains the following categories: differentiated but equal participation; equal participation; female appreciably more; females only; males only; and males appreciably more. Using this variable, we construct our indicator for female participation in agriculture which is a dummy variable equal 1 if there was differentiated but equal participation, there was equal participation, women participated more, or if women only participated, and zero otherwise. Descriptive statistics reported in Table 1 suggest that $64 \%$ of women in the sample belongs to ethnic groups where there was equal gender participation or women participated more in agricultural activities.

Murdock's Atlas also reports detailed information on a number of marriage traditions. One of these marriage traditions that we focus on in this paper is the bride price custom. Bride price is a transfer in cash or in kind made by the groom or his family to the bride's family. Based on the payment categories listed in Murdock's Atlas, we define bride price as a dummy equal to 1 if the prevalent mode of marriage payment prior to industrialization 
was equivalent to a transfer of bride price or wealth to the bride's family, an exchange of a bride service to the bride's family, or a payment of a token bride price, and zero otherwise. ${ }^{5}$ In our sample, $66 \%$ of women belongs to ethnic groups that traditionally practise bride price payment upon marriage.

The last traditional norm that we consider in this paper is the post-marital settlement rule. Murdock distinguishes between the following post-marital residence categories: Patrilocal, Virilocal, Ambilocal, Avunculocal, Uxorilocal, Matrilocal, Neolocal, No common residence, Optionally patrilocal, Optionally uxorilocal or avunculocal. We define the variable patrilocality as a dummy equal to 1 if the ethnic group follows the patrilocal or the virilocal post-marital residence rule; and zero otherwise. Table 1 shows that $67 \%$ of women in our sample originate from patrilocal societies.

\section{Identification Strategy}

\subsection{Baseline Specification}

Our goal is to estimate the causal impact of legal origins on women's empowerment, and to analyze how this effect varies with ancestral norms of gender roles. To identify this effect, we implement a spatial Regression Discontinuity Design with ethnic homeland fixed effects. Relying on the quasi-natural experiment that occurred during the "Scramble for Africa", our methodology exploits the arbitrary drawing of African borders and the fact that it splits ancestral ethnic homelands across countries with different legal traditions. Our main empirical specification is represented by the following equation:

$$
Y_{i p c e t}=\alpha+\beta \text { Common }_{c}+f\left(B_{p c e}\right)+\delta_{e}+\gamma_{t}+\theta_{r}+X_{i p c e t}^{\prime} \sigma+Z_{p c e}^{\prime} \mu+\varepsilon_{i p c e t}
$$

The dependent variable $Y_{i p c e t}$ reflects the outcome of interest for a women $i$, born at time $t$, and whose current residence is on the historical homeland of ethnic group $e$,

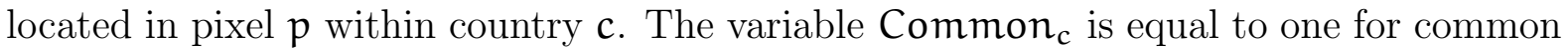
law countries and zero for civil law countries. $\beta$ is the coefficient of interest. It measures the local average effect of common law (vs. civil law) traditions on the outcome of interest. $\delta_{e}, \gamma_{\mathrm{t}}$, and $\theta_{\mathrm{r}}$ correspond to ethnic homeland fixed effects, cohort of birth fixed effects, and religion fixed effects, respectively. $X_{i p c e t}^{\prime}$ is a vector of individual controls including age and age squared. In most specifications we control for a rich set of location and geographical variables including the shortest distances from the centroid of the pixel to the coastline and to the national border, area under water, elevation, soil suitability for

\footnotetext{
${ }^{5}$ The other categories in Murdock's Atlas include: absence of consideration, gift exchange reciprocal, sister or female relative exchanged for bride.
} 
agriculture, pixel area, and natural resources. These variables are measured at the pixel level and are denoted by the vector $Z_{\text {pce }}^{\prime}$.

The running variable in our RD specification is given by the distance from the centroid of each pixel to the nearest national border with different legal origins. To allow the intercept of the relationship between the outcome of interest and the running variable to be different on each side of the border, we add to our baseline specification a local quadratic polynomial of the distance from the centroid of each pixel to the nearest national border with different legal origins. This non-parametric functional form is represented by $\mathrm{f}\left(\mathrm{BD}_{\mathrm{pce}}\right)$. Yet, we will show in Section 5 that our results are robust to a specification that considers a cubic RD polynomial of the distance from the centroid of each pixel to the nearest national border with different legal origins. To account for the multidimensional nature of the cut-off in a spatial RDD, we follow Dell (2010) and show that our results are also robust to controlling for a cubic RD polynomial in latitude and longitude of the pixel.

In our setting, non-adjusted standard errors are likely to be bias due to autocorrelation. As several ethnic homelands in the same country will have similar legal origins, clustering standard errors at the country-level is required. Moreover, given that Murdock (1959) identifies more that 800 pre-colonial ethnic groups across Africa and assigns them into 96 ethnolinguistic families, clustering at the ethnic-family level is also relevant. Following Cameron et al. (2011) we, therefore, cluster standard errors along both the country and the ethnic-family dimensions. In addition to account for the aforementioned concerns, the double-clustering parameterization also accounts for arbitrary residual correlation within each dimension.

\subsection{Validity of the Identification Strategy}

Our identification strategy consists in comparing the outcome of interest for women within the historical homeland of the same ethnic group in adjacent countries with different legal origins. There are two key assumptions underlying this empirical strategy. The first assumption requires that assignment across common and civil law traditions is as good as random. Put differently, the border between civil and common law countries should not be influenced by factors that themselves determine the outcome of interest. This interpretation is supported by the extensive historical and economic literature providing evidence that African borders were drawn in an arbitrary manner (see, for instance, Michalopoulos and Papaioannou $(2015,2013)$ for an extensive review of this literature). The central argument in this literature is that at the time of the "Scramble for Africa", in the late 19th century, Europeans divided Africa with limited knowledge of local conditions.

The second identification assumption requires that relevant determinants of the outcome of interest, besides the treatment, should not systematically vary at the border. 
In our setting it means that ethnic areas across the border should be similar across all relevant determinants of women's empowerment, with the exception of legal origins. We empirically investigate whether differences in legal origins translate into differences in various geographical characteristics of the ethnic homeland that are likely to influence women's empowerment outcomes. Table 2 reports the RD estimates that associate geographic, ecological, and natural resources measures with legal origins. We focus in this analysis on pixels falling within $60 \mathrm{~km}$ on each side of the national border. Results are supportive of our empirical strategy. In general, we find no significant effect of common law on any of the numerous geographic, ecological, and natural resources measures. Even though this result ensures that the two areas of the same ethnic homeland partitioned between civil and common law countries are good counterfactual, we control for these geographical characteristics in our empirical analysis.

\section{$5 \quad$ Regression Discontinuity Results}

In this section, we formally implement the RD design described in Section 4 to estimate the long-term impact of legal origins on women empowerment in a variety of cultural contexts. The first subsection describes the average causal impact of common law (vs. civil law) on women empowerment outcomes. The second subsection describes how this effect depends on ancestral ethnic norms which may determine gender roles.

\subsection{Legal Origins and Female Empowerment}

\subsubsection{Female Education}

The theoretical literature on the historical determinants of female education suggests that there should be a positive relationship between the common law system and female education. We test this proposition by estimating equation 1 using four key outcome variables: an indicator for the total number of years of education and three dummies indicating whether the respondent has completed at least one year of schooling, primary education, and secondary education, respectively. Before presenting these estimation results, we first provide a graphical illustration of the RD estimates.

The RD plots are displayed in Figure 2 where the running variable is given by the geodesic distance (in kilometers) from the centroid of each pixel to the nearest national border with different legal origins. The vertical red line represents the national border in adjacent countries with different legal origins. Each graph plots, for individuals within bins of 5 kilometer width, the average of the outcome of interest predicted using equation 1. ${ }^{6}$ We report result using a 100 kilometer bandwidth. Each RD graph also plots the

\footnotetext{
${ }^{6} \mathrm{GPS}$ latitude/longitude positions are randomly displaced in the DHS by a maximum of 5 kilometers. This is to ensure confidentiality. This random displacement should not affect our findings since the
} 
estimated values from a local polynomial regression of the outcome of interest on the running variable fitted separately using data from common law countries (where the running variable takes on positive values) and data from civil law countries (where the running variable takes on negative values). We see from Figures 2- $a$ to $2-d$ that regardless of how we measure female education, women living in common law countries are significantly more educated than women living in civil law countries.

The positive association between the common law legal system and female education is corroborated in the regressions results. Table 3 presents results from estimating equation 1. This table shows the RD estimates of the effect of the common law system (in comparison to the civil law) on our four key measures of female education. In Panel A, the dependent variable is the total number of years of education. In Panels $B, C$, and $D$, the dependent variables are dummies indicating whether a woman has completed at least one year of schooling, primary education, and secondary education, respectively. Each specification in this table controls for ethnic homelands fixed effects, age and age squared, cohort of birth fixed effects, and religion fixed effects. For inference purpose, and to account for spatial autocorrelation, robust standard errors adjusted for doubleclustering at the country and ethno-linguisic family are reported in parentheses. We start by displaying results using a naive within-ethnic homeland Ordinary Least Squares (OLS) regressions without the RD polynomial in column (1). In columns (2)-(5), we present the RD estimates using different choices of bandwidths and controlling for a quadratic RDpolynomial in the distance from the centroid of each pixel to the national border with different legal origins.

Across all specifications, we find results consistent with the RD graphs. We see a statistically significant positive impact of common law on female education. This result holds regardless of how we measure female education. For example, Panel $A$ shows that the total number of years of education is between 1.2 and 1.7 greater for women in common law countries compared to their counterparts in civil law countries. This effect is large in magnitude. It implies that the female educational level is about $38 \%$ higher in common law countries, as the average educational attainment throughout the region examined in this paper is 3.12 years of education.

Although we have shown that areas on the two sides of the border display balanced geographical characteristics and are thus good counterfactuals (see Table 2), we nevertheless control for these characteristics in alternative specifications. Results are shown in Panels $E-H$ of Table 3. Controlling for geographic features including altitude, soil suitability for agriculture, area under water, natural resources, and distance to the sea coast does not change our results. Additionally, Appendix tables A2 and A3 also probe the robustness of our results to specifications that control for different functional forms of the RD-polynomial including a cubic polynomial in distance to the nearest national displacement is done within the region of residence of the respondents. 
border with different legal origins and a polynomial in latitude-longitude.

We also check whether the effect of the common law on female education is fading away over time. In Appendix Table A4, we split our sample into two subgroups: women born before or in 1976 and women born after 1976, respectively. This year is chosen to obtain subsamples of equal size. We find that the estimated effect is larger for younger cohorts, suggesting that the disparities in education between women of similar ethnic groups in common and civil law countries is not fading away.

\subsubsection{Female Employment and Marriage}

In Table 4, we report estimates of the effect of common law on women's employment and marriage outcomes. As in Table 3, we present the OLS estimates in column 1 and the RD estimates where we control for a second-order polynomial in the distance to the national border with different legal origins in columns (2)-(5).

DHS surveys report information about the type of occupation in which the respondent is currently working. The categories include non-agricultural high skilled workers, agricultural workers and low or unskilled workers. We focus on professional or high-skill activities as our objective is to measure the extent of female empowerment through female participation in activities that require a reasonable education level. In Panel A, we explore the impact of common law on the likelihood of working in the professional sector. The estimates show that women in common law countries are more likely to work in the professional sector. The estimates are statistically significant at conventional levels in most specifications. The estimates suggest that the common law system increases the likelihood to work in the professional sector by about 1 percentage point, which compared to the sample mean represents a rise of around $33 \%$.

Analogous estimates of the effect of common law on marriage outcomes are displayed in Panels $B-D$ of Table 4. We focus on measures of the risk of early marriage (that is marriage before age 16 or 18) and the age gap between spouses. We see that women in common law countries are less likely to marry at a young age. The effect is statistically significant only for the risk of marriage before age 18 (Panel $C$ ). Moreover, common law is positively associated with the age gap between a woman and her partner (Panel $D)$, but this effect is not significant at conventional levels.

Note that our results are also robust to specifications where we augment the baseline regression in equation 1 with a rich set of geographic controls. In results not shown, we find that these estimates are also robust to other functional forms of the RD polynomial. Overall, we find that women in common law countries are more likely to work in the professional sector and less likely to marry before the age 18 . 


\subsection{Heterogeneity: Ancestral Norms, Legal Origins, and Fe- male Empowerment}

We now turn to the analysis of how the presence of ancestral or traditional norms which determine gender roles may generate heterogeneity in the effect of legal origins. Following our conceptual framework in Section 2, we argue that the positive relationship between common law and women's empowerment outcomes should be lower in societies with ancestral norms that foster gender inequality including: (1) norms of low female participation in agriculture, (2) norms of bride price payment, and (3) patrilocal norms.

Before turning to this analysis, we first check whether these traditional norms are significantly related to female education. Appendix Table A5 reports estimates in which the dependent variable is the number of years of education for women in our sample and the variables of interest are our three traditional norms. Columns 1, 3 and 5 do not include control variables, whereas columns 2,4 and 6 control for age and age-squared. Overall, we find strong evidence that women living in societies that traditionally fostered gender inequality are less educated. In columns 1 and 2 , we find that women currently living in societies with a traditional norm of high female participation in agriculture are significantly more educated. The estimates presented in columns 3 and 4 suggest that respondents living in societies with the bride price are less educated. Last, columns 5 and 6 present evidence that women in societies with a patrilocal norm are also less educated.

We now test our main hypotheses by comparing the causal impact of legal origins in different cultural contexts resulting from the three aforementioned traditional norms of gender roles. Formally, we split our sample in two subsamples depending on whether or not the respondent belongs to an ethnic group that traditionally practised the corresponding norm (e.g., bride price). We then estimate equation 1 separately for each subsample. Results are reported in Tables 5 and 6 . In each of these tables, we present results for observations falling within 60 kilometers on each side of the national border with different legal origins. Across all specifications in these tables, we control for ethnic homeland fixed effects, age and age-squared, cohort of birth fixed effects, religion fixed effects, a second-order RD polynomial in distance to the national border with different legal origins, and a set of geographical features. We corroborate findings in Tables 5 and 6 by estimating a variant of equation 1 where we interact the common law dummy with the ancestral norm indicator variable. Results using the latter specification are reported in Appendix Table A6.

\subsubsection{Female Participation in Agriculture}

Our first hypothesis is that the impact of common law on female education is stronger in societies where, historically, women were highly involved in agriculture. As discussed in Section 3, we measure female participation in agriculture using ethnographic sources. 
Results from estimating the effect of legal origins on female education separately for ethnic groups with high female participation in agriculture and those with low female participation in agriculture are reported in columns (1) and (2) of Table 5, respectively. In Panel $A$, the dependent variable is the total number of years of education. We see that the effect of common law on female education is positive and significant in the two subsamples. However, consistent with the first hypothesis, the positive effect of common law on the number of years of education is greater for women originating from societies where women were highly involved in agricultural activities. Estimates suggest that women in common law countries have $2.5(0.9)$ years of education more in common law countries for the subsample of societies where, historically, women were (not) highly involved in agriculture. Similarly, women in common law countries are significantly more likely to have graduated from primary and/or secondary school than women in civil law countries in societies where women were highly involved in agricultural activities (Panels $B-D)$.

These results are consistent with the idea that in societies that historically encouraged women's participation in productive activities, institutions or policies that decrease the price or the relative price of education incentivize parents to invest more in girls' education.

In Table 6, we focus on the heterogeneous impact of legal origins on women's employment and marital outcomes. The results in the first two columns show that women are significantly more likely to work in the professional sector only in societies where in the past women were highly involved in agricultural activities. In contrast, the effect is small and not statistically different from zero in ancestral societies with low female participation in agriculture. This result is also consistent with the stronger positive impact of common law on female education in ancestral societies characterized by high female participation in agricultural activities.

Examining heterogeneity in the effect of common law on marriage outcomes also reveals that the negative impact of common law on the risk of early marriage is only observable for women originating from societies with high participation of women in agricultural activities. Similarly, we find that the age gap between the spouses is significantly lower for women in common law countries only when in the past, women were highly involved in agricultural activities. On average, the age gap is 0.7 years lower in common law (vs. civil law) countries among ethnic groups that traditional promote the participation of women in subsistence activities. In contrast, the age gap is significantly larger in common law (vs. civil law) countries among ethnic groups where historically women were less likely to participate in productive activities. These results imply that the average positive effect of common law on the partner age gap (see Table 4) in fact mask important heterogeneity depending on the cultural context. 


\subsubsection{Bride Price}

The second hypothesis is that the impact of common law on female education will be stronger in societies that do not practise bride price payment. Using the indicator of bride price custom defined in Section 3, we split the sample into two subgroups depending on whether the respondent belongs to an ethnic group that traditionally practise bride price payment upon marriage.

Results from estimating the effect of common law on female education separately in each subsample are displayed in columns (3) and (4) of Table 5). Common law has a positive and statistically significant impact on female education (in all panels) in both subgroups with and without bride price payment. But, consistent with the theory, the positive effect of common law on education is greater for non-bride price ethnic groups. The estimated effect suggests that common law increases the number of years of education by about 2.5 in non-bride price ethnic groups, while this effect is only 0.70 in bride price ethnic groups.

Columns (3) and (4) of Table 6 report heterogeneous effects of common law on female employment and marital outcomes by bride price custom. Consistent with its heterogeneous effects on female education, we also find that the estimated of common law on a woman's chance of working in the professional sector is significantly greater only in the non-bride price ethnic groups (Panel $A$ ). In addition, we also find that for the non-bride price ethnic groups, the risk of early marriage and the age gap between the spouses are significantly lower in common law (vs. civil law) countries, while in societies that practise bride price payment, we observe no effect of common law on early marriage and a positive effect on the husband-wife age gap (Panels $B-D)$.

\subsubsection{Patrilocality versus Matrilocality}

Our third hypothesis is that the positive impact of common law on female education is stronger in matrilocal (vs. patrilocal) societies. As previously discussed, matrilocal postmarital residence increases parental financial connections with daughters relative to sons, and it generates a greater incentive for parents to invest in their daughters' human capital. As a result, the response to a decline in the price of education is likely to be stronger for female education in matrilocal societies. This interpretation is consistent with the empirical results shown in columns (5) and (6) of Table 5. In this table, we estimate the effect of common law separately in matrilocal and patrilocal societies. We see that the positive effect of common law on female education is much greater for women in matrilocal societies compared to patrilocal societies. For instance, in matrilocal societies, we find that women in common law (vs. civil law) countries have, on average, 2.5 more years of education. In comparison, in patrilocal societies, women in common law countries have only 0.72 more years of education than their counterparts in civil law countries. 
Finally, estimates showing how the effects of legal origins on female employment and marriage outcomes depend on the post-marital residence rule are displayed in columns (5) and (6) of Table 6. Consistent with the findings uncovered so far, we find that common law has a positive and significant impact on the likelihood of working in the professional sector only in matrilocal ethnic groups (Panel A). Moreover, common law has a significant negative impact on the risk of early marriage and on the age gap between the spouses only in matrilocal societies (Panels $B-D$ ).

All of these findings are consistent with the predictions of our model.

\subsubsection{Ancestral Norms, Legal Origins, and Male Education}

The heterogeneous results describe above imply that, formal institutions that sufficiently reduce the cost (or the relative cost) of education, such as the common law system, provide incentives for parents to invest more in their daughters' education only in settings with traditional norms that historically foster women's empowerment. This conclusion is strengthened by the regression results showing the effect of legal origins on male education. We see in Appendix Table A7 that common law has a stronger benefit for male education mainly in societies where ancestral norms of gender roles do not promote women's rights. Appendix Table A7 shows that the positive impact of common law on male education is much larger in societies where women were not involved in agricultural activities, and that this positive impact is only present in bride price societies and in patrilocal societies. These findings are consistent across all the measures of education we examine.

Overall, the heterogeneous effect of common law on women's outcomes strongly suggests that, to be optimal, the design of formal institutions should take into account the cultural and traditional context in which they will be implemented. An alternative interpretation of our findings is that better formal institutions can attenuate the negative impact of ancestral cultural norms that constrain women's rights on their economic empowerment. Indeed, as we have shown, ancestral norms that constrain women's rights negatively affect their outcomes (Appendix Table A5), but these negative effects are attenuated by the common law system (Appendix Table A6). This interpretation has important policy relevance, especially given that formal institutions are easier to change than ancestral traditions. Finally, the fact that the common law system positively affects male education mainly in societies that do not traditionally promote women's rights suggests traditional norms of gender roles directly oppose women's rights to men's rights, which in turn implies that the design of formal institutions aimed to address the plight of women in societies that constrain them should win the support of men. 


\section{Conclusion}

In this paper, we studied the interplay of legal origins and ancestral cultural norms of gender roles in shaping female economic empowerment in sub-Saharan Africa. We analyzed outcomes such as female education, female employment, early marriage, and the husband-wife age gap. Exploiting the arbitrary division of ancestral ethnic homelands across countries with different legal origins, we directly compared women among the same ethnic group living in civil law countries and common law countries. We found that, on average, women in common law countries are significantly more educated than their counterparts in civil law countries. Similarly, they are more likely to work in the professional sector, and are less likely to marry at young age.

These effects are either absent or significantly lower in settings where ancestral cultural norms do not promote women's rights and empowerment. In particular, we found little effect in bride price societies, patrilocal societies, and societies where women were not involved in agriculture in the past. An alternative interpretation of our findings is that better formal institutions can significantly attenuate the negative impacts of traditional cultural norms that constrain women's rights. In addition, the results suggest that the ancestral promotion of women's rights directly opposes that of men's rights, as we found a positive effect of the common law system on male education mainly in societies that do not traditionally promote women's rights. Our findings imply that, to be optimal, the design of legal institutions should account for ancestral traditions. Indeed, legal origins and institutions alone might not be enough to promote women's economic outcomes. The interplay between deeply-rooted cultural norms and economic and legal institutions is key to ensure significant progress in important dimensions of women's economic empowerment. 


\section{References}

Acemoglu, D., \& Johnson, S. (2005). Unbundling Institutions. Journal of Political Economy, 113(5), 949-995.

Albanesi, S., \& Olivetti, C. (2016). Gender Roles and Medical Progress. Journal of Political Economy, 124(3), 650-695.

Alesina, A., Brioschi, B., \& La Ferrara, E. (2016). Violence Against Women: A CrossCultural Analysis for Africa. NBER Working Paper 21901.

Alesina, A., \& Giuliano, P. (2015). Culture and Institutions. Journal of Economic Literature, 53(4), 898-944.

Alesina, A., Giuliano, P., \& Nunn, N. (2013). On the Origins of Gender Roles: Women and the Plough. Quarterly Journal of Economics, 128(2), 469-530.

Alesina, A., Michalopoulos, S., \& Papaioannou, E. (2016). Ethnic Inequality. Journal of Political Economy, 124(2), 428-488.

Anderson, S. (2007). The Economics of Dowry and Brideprice. Journal of Economic Perspectives, 21(4), 151-174.

Anderson, S. (2018). Legal Origins and Female HIV. American Economic Review, 108(6), 1407-39.

Ansell, N. (2001). "Because it's Our Culture!"(Re) negotiating the Meaning of Lobola in Southern African Secondary Schools. Journal of Southern African Studies, 27 (4), 697-716.

Ashraf, N., Bau, N., Nunn, N., \& Voena, A. (2020). Bride Price and Female Education. Journal of Political Economy, 128(2), 591-641.

Banerjee, A., \& Iyer, L. (2005). History, Institutions, and Economic Performance: The Legacy of Colonial Land Tenure Systems in India. American Economic Review, 95(4), 1190-1213.

Basu, A. M. (n.d.). Anthropological insights into the links between women's status and demographic behaviour, illustrated with the notions of hypergamy and territorial exogamy.

Basu, A. M. (1992). Culture, the Status of Women, and Demographic Behaviour: Illustrated with the Case of India.

Bau, N. (2020). Can Policy Change Culture? Government Pension Plans and Traditional Kinship Practices.

Beck, T., Demirgüç-Kunt, A., \& Levine, R. (2003). Law, Endowments, and Finance. Journal of Financial Economics, 70(2), 137-181.

Bisin, A., \& Verdier, T. (2017). On the Joint Evolution of Culture and Institutions. NBER Working Paper 23375.

Bleakley, H., \& Lin, J. (2012). Portage and Path Dependence. Quarterly Journal of Economics, 127(2), 587-644. 
Boserup, E. (1970). Women's Role in Economic Development. American Journal of Agricultural Economics, 53(3), 536-537.

Buttenheim, A. M., \& Nobles, J. (2009). Ethnic Diversity, Traditional Norms, and Marriage Behaviour in Indonesia. Population Studies, 63(3), 277-294.

Cameron, A., Gelbach, J., \& Miller, D. (2011). Robust Inference With Multiway Clustering. Journal of Business \& Economic Statistics, 29(2), 238-249.

Canning, D., Mabeu, M. C., \& Pongou, R. (2020). Colonial Origins and Fertility: Can the Market Overcome History? Unpublished Manuscript.

Carranza, E. (2014). Soil Endowments, Female Labor Force Participation, and the Demographic Deficit of Women in India. American Economic Journal: Applied Economics, 6(4), 197-225.

Cogneau, D., Mesplé-Somps, S., \& Spielvogel, G. (2013). Development at the Border: Policies and National Integration in Côte d'Ivoire and its Neighbors. World Bank Economic Review, 29(1), 41-71.

Cogneau, D., \& Moradi, A. (2014). Borders that Divide: Education and Religion in Ghana and Togo since Colonial Times. Journal of Economic History, 74(3), 694729.

Corno, L., Hildebrandt, N., \& Voena, A. (2016). Weather Shocks, Age of Marriage and the Direction of Marriage Payments. Working Paper.

Corno, L., \& Voena, A. (2016). Selling Daughters: Age of Marriage, Income Shocks and the Bride Price Tradition. IFS working paper W16/08.

Dell, M. (2010). The persistent effects of peru's mining mita. Econometrica, 78(6), 1863-1903.

Dell, M., Lane, N., \& Querubin, P. (2018). The Historical State, Local Collective Action, and Economic Development in Vietnam. Econometrica, 86 (6), 2083-2121.

Djankov, S., Porta, R. L., de Silanes, F. L., \& Shleifer, A. (2002). The Regulation of Entry. Quarterly Journal of Economics, 117(1), 1-37.

Doepke, M., \& Tertilt, M. (2009). Women's Liberation: What's in it for Men? Quarterly Journal of Economics, 124(4), 1541-1591.

Doepke, M., Tertilt, M., \& Voena, A. (2012). The Economics and Politics of Women's Rights. Annual Review of Economics, 4(1), 339-372.

Duflo, E. (2012). Women Empowerment and Economic Development. Journal of Economic Literature, 50(4), 1051-79.

Duflo, E., \& Udry, C. (2004). Intrahousehold Resource Allocation in Cote d'Ivoire: Social Norms, Separate Accounts, and Consumption Choices. NBER Working Paper No. 10498.

Dupraz, Y. (2019). French and British Colonial Legacies in Education: Evidence from the Partition of Cameroon. Journal of Economic History, 79(3), 628-668.

Dyson, T., \& Moore, M. (1983). On Kinship Structure, Female Autonomy, and Demo- 
graphic Behavior in India. Population and Development Review, 35-60.

Fernández, R. (2007). Women, Work, and Culture. Journal of the European Economic Association, 5(2-3), 305-332.

Fernández, R., \& Fogli, A. (2009). Culture: An Empirical Investigation of Beliefs, Work, and Fertility. American Economic Journal: Macroeconomics, 1(1), 146-77.

Fernández, R., Fogli, A., \& Olivetti, C. (2004). Mothers and Sons: Preference Formation and Female Labor Force Dynamics. Quarterly Journal of Economics, 119(4), 12491299

Galor, O., \& Moav, O. (2002). Natural Selection and the Origin of Economic Growth. Quarterly Journal of Economics, 117(4), 1133-1191.

Glaeser, E. L., \& Shleifer, A. (2002). Legal Origins. Quarterly Journal of Economics, $117(4), 1193-1229$.

Goldin, C. (2006). The Quiet Revolution that Transformed Women's Employment, Education, and Family. American Economic Review, 96(2), 1-21.

Hague, G., Thiara, R. K., \& Turner, A. (2011). Bride-Price and its Links to Domestic Violence and Poverty in Uganda: A Participatory Action Research Study. Women's Studies International Forum, 34(6), 550-561.

Hansen, C. W., Jensen, P. S., \& Skovsgaard, C. V. (2015). Modern Gender Roles and Agricultural History: the Neolithic Inheritance. Journal of Economic Growth, $20(4), 365-404$.

Hayek, F. A. (1973). Law, Legislation, and Liberty. University of Chicago Press.

Heath, R., \& Jayachandran, S. (2016). The Causes and Consequences of Increased Female Education and Labor Force Participation in Developing Countries. National Bureau of Economic Research.

Jayachandran, S. (2015). The Roots of Gender Inequality in Developing Countries. Annual Reviews of Economics, 7(1), 63-88.

Jedwab, R., Kerby, E., \& Moradi, A. (2017). History, Path Dependence and Development: Evidence from Colonial Railways, Settlers and Cities in Kenya. Economic Journal, 127(603), 1467-1494.

Joireman, S. F. (2001). Inherited Legal Systems and Effective Rule of Law: Africa and the Colonial Legacy. Journal of Modern African Studies, 39(4), 571-596.

Joireman, S. F. (2008). The Mystery of Capital Formation in Sub-Saharan Africa: Women, Property Rights and Customary Law. World Development, 36(7), 12331246.

Karve, I. (1953). Kinship organisation. Deccan College Monograph Series, Poona, India: Deccan College Post-graduate and Research Institute, 10.

Kizito, M. (2013). Child Marriage in Tanzania: Cash for Parents, Problems for Girls. Newspaper article, Thomson Reuters Foundation.

Klerman, D. M., Mahoney, P. G., Spamann, H., \& Weinstein, M. I. (2011). Legal Origin 
or Colonial History? Journal of Legal Analysis, 3(2), 379-409.

La Porta, R., de Silanes, F. L., Shleifer, A., \& Vishny, R. W. (1998). Law and Finance. Journal of Political Economy, 106(6), 1113-1155.

La Porta, R., Lopez-de Silanes, F., \& Shleifer, A. (2008). The Economic Consequences of Legal Origins. Journal of Economic Literature, 46(2), 285-332.

La Porta, R., Lopez-de Silanes, F., Shleifer, A., \& Vishny, R. (1999). The Quality of Government. Journal of Law, Economics, and Organization, 15(1), 222-279.

La Porta, R., Lopez-de Silanes, F., Shleifer, A., \& Vishny, R. W. (1997). Legal Determinants of External Finance. Journal of Finance, 1131-1150.

Levine, D., \& Kevane, M. (2003). Are Investments in Daughters Lower when Daughters Move Away? Evidence from Indonesia. World Development, 31(6), 1065-1084.

Lowes, S., \& Nunn, N. (2017). Bride Price and the Wellbeing of Women. Towards Gender Equity in Development, 117-138.

Mahoney, P. G. (2001). The Common Law and Economic Growth: Hayek Might be Right. Journal of Legal Studies, 30(2), 503-525.

Malhotra, A., Vanneman, R., \& Kishor, S. (1995). Fertility, Dimensions of Patriarchy, and Development in India. Population and Development Review, 281-305.

Michalopoulos, S., \& Papaioannou, E. (2013). Pre-Colonial Ethnic Institutions and Contemporary African Development. Econometrica, 81(1), 113-152.

Michalopoulos, S., \& Papaioannou, E. (2014). National Institutions and Subnational Development in Africa. Quarterly journal of economics, 129(1), 151-213.

Michalopoulos, S., \& Papaioannou, E. (2015). On the Ethnic Origins of African Development: Traditional Chiefs and Pre-Colonial Political Centralization. Academic of Management Perspectives, 29(1), 32-71.

Michalopoulos, S., \& Papaioannou, E. (2016). The Long-Run Effects of the Scramble for Africa. American Economic Review, 106(7), 1802-48.

Michalopoulos, S., Putterman, L., \& Weil, D. N. (2019). The Influence of Ancestral Lifeways on Individual Economic Outcomes in Sub-Saharan Africa. Journal of the European Economic Association, 17(4), 1186-1231.

Mtui, J. (2013). Bride Price to Unborn Girls Deplorable Custom. Daily News, Tanzania's leading online new edition.

Murdock, G. P. (1959). Africa: its peoples and their culture history. McGraw-Hill Book Company, New York.

Murdock, G. P. (1967). Ethnographic Atlas: a Summary. Ethnology, 6(2), 109-236.

North, D. C. (1989). Institutions and Economic Growth: An Historical Introduction. World Development, 17(9), 1319-1332.

Nunn, N. (2012). Culture and the Historical Process. Economic History of Developing Regions, 27(sup1), S108-S126. 
Nunn, N., Akyeampong, E., Bates, R., \& Robinson, J. A. (2014). Gender and Missionary Influence in Colonial Africa. African Development in Historical Perspective.

Pitt, M. M., Rosenzweig, M. R., \& Hassan, M. N. (2012). Human Capital Investment and the Gender Division of Labor in a Brawn-Based Economy. American Economic Review, 102(7), 3531-60.

Rammohan, A., \& Robertson, P. (2012). Do Kinship Norms Influence Female Education? Evidence from Indonesia. Oxford Development Studies, 40(3), 283-304.

Teso, E. (2019). The Long-Term Effect of Demographic Shocks on the Evolution of Gender Roles: Evidence from the Transatlantic Slave Trade. Journal of the European Economic Association, 17(2), 497-534.

United Nations. (2015). The World's Women 2015: Trends and Statistics. Department of Economic and Social Affairs, Statistics Division.

Watson, A. (1993). Legal transplants: an approach to comparative law. University of Georgia Press. 
Figure 1: Ethnic homelands partitioned between civil and common law countries

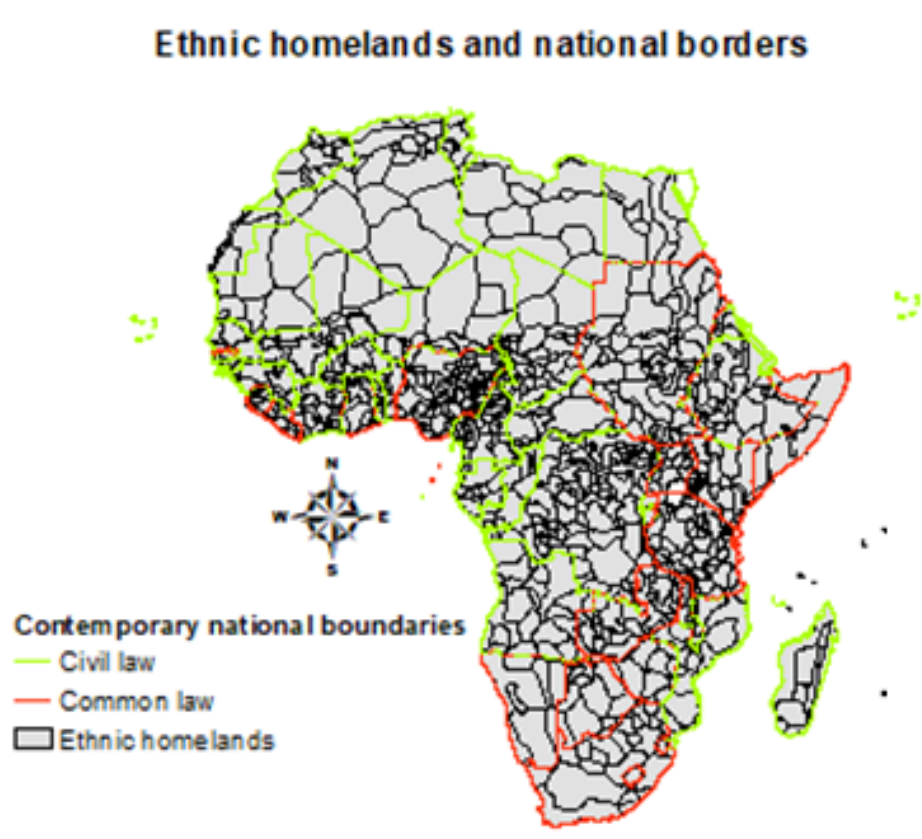

Ethnic groups split between civil law and comon law countries

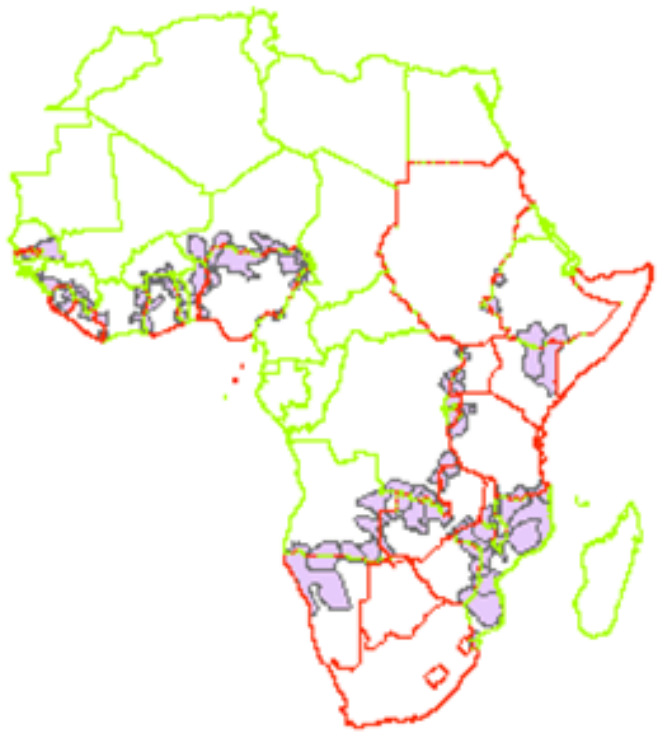


Figure 2: Average effects: Legal origins and female education
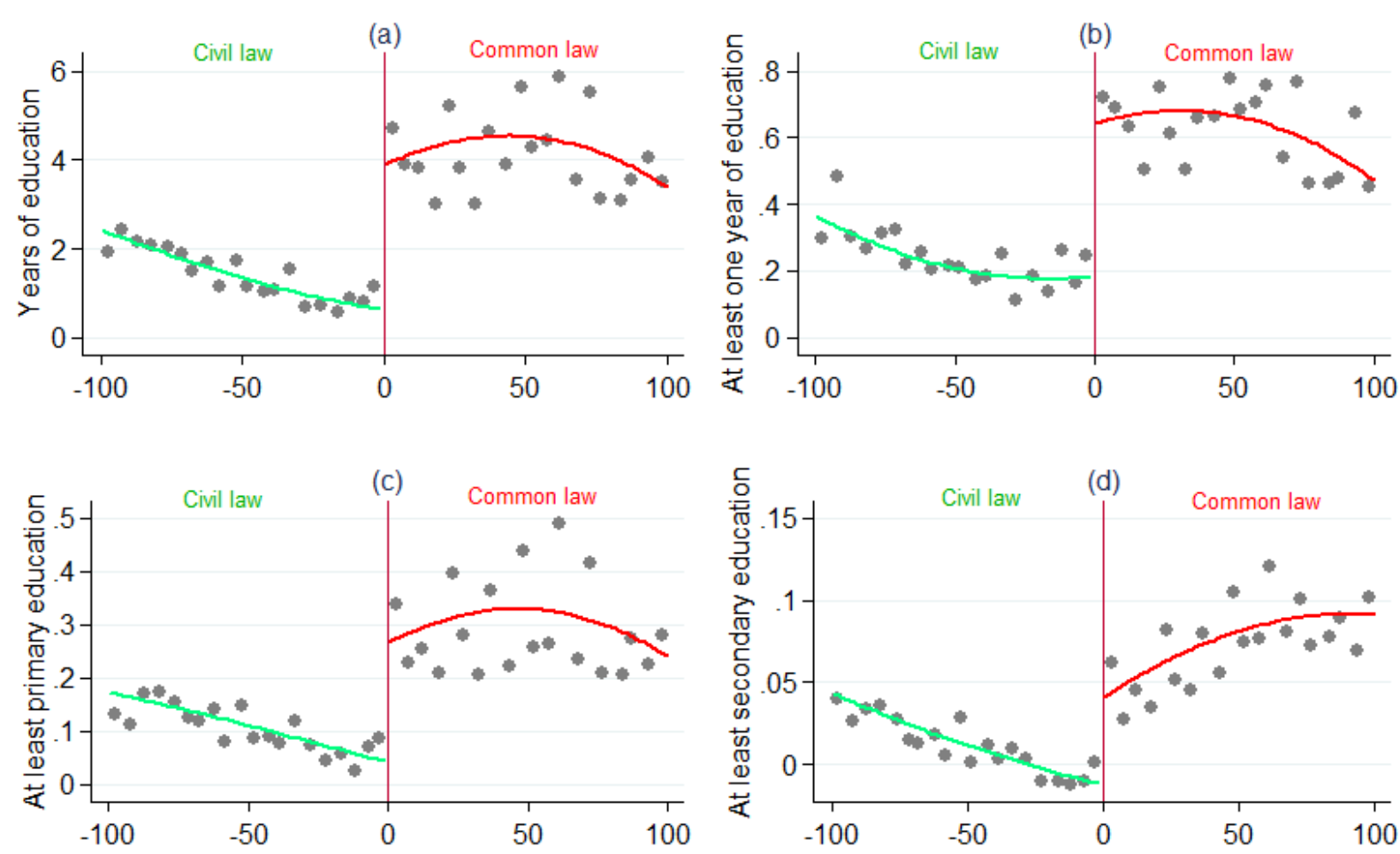

Distance to border

Positive Values: $5 \mathrm{~km}$ Bins in common law countries

Negative Values: $5 \mathrm{~km}$ Bins in civil law countries 
Table 1: Descriptive Statistics - Individual level data

\begin{tabular}{lccccc}
\hline & $\mathrm{N}$ & Mean & Std. dev. & Min. & Max. \\
\hline Years of education & 8,406 & 3.29 & 3.98 & 0 & 17 \\
Has no education & 8,406 & 0.52 & 0.50 & 0 & 1 \\
Has at least primary education & 8,417 & 0.24 & 0.43 & 0 & 1 \\
Has at least secondary education & 8,417 & 0.05 & 0.21 & 0 & 1 \\
Year of birth & 8,419 & 1974 & 9.48 & 1948 & 1994 \\
Age at survey & 8,419 & 31.59 & 8.24 & 20 & 49 \\
Mother is married & 7,930 & 0.70 & 0.46 & 0 & 1 \\
Early marriage (before age 16) & 7,016 & 0.32 & 0.47 & 0 & 1 \\
Early marriage (before age 18) & 7,016 & 0.56 & 0.50 & 0 & 1 \\
Percentage of muslim & 8,400 & 0.33 & 0.47 & 0 & 1 \\
Percentage of christian & 8,400 & 0.46 & 0.50 & 0 & 1 \\
Husband-wife age gap & 6,188 & 8.42 & 7.49 & -16 & 57 \\
Respondent's working & 7,909 & 0.69 & 0.46 & 0 & 1 \\
Professional sector & 7,909 & 0.03 & 0.17 & 0 & 1 \\
Female participation in agriculture & 6,987 & 0.64 & 0.48 & 0 & 1 \\
Bride price & 7,321 & 0.66 & 0.47 & 0 & 1 \\
Patrilocality & 7,211 & 0.67 & 0.47 & 0 & 1 \\
\hline
\end{tabular}

Note: This table reports the mean, standard deviation, minimum and maximum for our variables of interest. 
Table 2: Validity of identification design at the pixel level

\begin{tabular}{|c|c|c|c|c|c|c|c|}
\hline & \multicolumn{7}{|c|}{ Dependent variable is: } \\
\hline & $\begin{array}{l}\text { Elevation } \\
(1)\end{array}$ & $\begin{array}{l}\text { Soil suitability } \\
\qquad(2)\end{array}$ & $\begin{array}{c}\text { Area under water } \\
(3)\end{array}$ & $\begin{array}{c}\text { Pixel area } \\
(4)\end{array}$ & $\begin{array}{l}\text { Diamonds } \\
(5)\end{array}$ & $\begin{array}{l}\text { Dist. to the border } \\
(6)\end{array}$ & $\begin{array}{l}\text { Dist. to sea } \\
(7)\end{array}$ \\
\hline Common law & $\begin{array}{c}45.49 \\
(47.734)\end{array}$ & $\begin{array}{l}0.07^{* * *} \\
(0.006)\end{array}$ & $\begin{array}{c}6.71 \\
(4.942)\end{array}$ & $\begin{array}{c}2.55 \\
(3.865)\end{array}$ & $\begin{array}{c}0.00 \\
(0.002)\end{array}$ & $\begin{array}{c}-0.11 \\
(0.881)\end{array}$ & $\begin{array}{c}9.16 \\
(41.456)\end{array}$ \\
\hline $\mathrm{N}$ & 437 & 434 & 437 & 437 & 437 & 437 & 437 \\
\hline Countries & 13 & 13 & 13 & 13 & 13 & 13 & 13 \\
\hline Ethnic Families & 23 & 23 & 23 & 23 & 23 & 23 & 23 \\
\hline Ethnic homeland FE & $\checkmark$ & $\checkmark$ & $\checkmark$ & $\checkmark$ & $\checkmark$ & $\checkmark$ & $\checkmark$ \\
\hline
\end{tabular}

Note: In each specification, the unit of observation is the pixel. The table reports RDD estimates associating various location and geographical characteristics at the pixel level with legal origins. In each specification we restrict the analysis to observations within $60 \mathrm{~km}$ of the border and we control for a second-order polynomial in the distance from the centroid of each pixel to the national border with different legal origins. Below the estimates, we report in parentheses standard errors clustered both at the country and the ethno-linguistic family levels. Coefficients that are significantly different from zero are denoted by the following system: $* * * p<0.01$, ${ }^{* *} p<0.05,{ }^{*} p<0.1$. 
Table 3: Average effects: Legal origins and female education

\begin{tabular}{|c|c|c|c|c|c|}
\hline & \multicolumn{5}{|c|}{ RDD - Bandwidth } \\
\hline & $\begin{array}{c}\text { OLS } \\
(1)\end{array}$ & $\begin{array}{l}<250 \mathrm{~km} \text { of bound. } \\
(2)\end{array}$ & $\begin{array}{l}<150 \mathrm{~km} \text { of bound. } \\
(3)\end{array}$ & $\begin{array}{c}<100 \mathrm{~km} \text { of bound. } \\
(4)\end{array}$ & $\begin{array}{c}<60 \mathrm{~km} \text { of bound. } \\
(5)\end{array}$ \\
\hline \multicolumn{6}{|c|}{ Baseline specification } \\
\hline Common law & $\begin{array}{l}1.74^{* * *} \\
(0.493)\end{array}$ & $\begin{array}{c}1.26^{* *} \\
(0.523)\end{array}$ & $\begin{array}{c}1.27^{* *} \\
(0.550)\end{array}$ & $\begin{array}{c}1.31^{* *} \\
(0.644)\end{array}$ & $\begin{array}{c}1.18^{* *} \\
(0.486)\end{array}$ \\
\hline Observations & 16,307 & 15,069 & 13,251 & 11,062 & 7,880 \\
\hline \multicolumn{6}{|c|}{ Panel B: Completed one year of schooling } \\
\hline Common law & $\begin{array}{l}0.22^{* * *} \\
(0.071)\end{array}$ & $\begin{array}{c}0.17^{* *} \\
(0.073)\end{array}$ & $\begin{array}{c}0.17^{* *} \\
(0.076)\end{array}$ & $\begin{array}{c}0.18^{* *} \\
(0.085)\end{array}$ & $\begin{array}{l}0.18^{* * *} \\
(0.069)\end{array}$ \\
\hline Observations & 16,307 & 15,069 & 13,251 & 11,062 & 7,880 \\
\hline \multicolumn{6}{|c|}{ Panel C: Completed primary schooling } \\
\hline Common law & $\begin{array}{l}0.12^{* * *} \\
(0.019)\end{array}$ & $\begin{array}{c}0.09 * * * \\
(0.025)\end{array}$ & $\begin{array}{c}0.09^{* * *} \\
(0.027)\end{array}$ & $\begin{array}{c}0.09^{* * *} \\
(0.034)\end{array}$ & $\begin{array}{l}0.07^{* * *} \\
(0.020)\end{array}$ \\
\hline Observations & 16,319 & 15,081 & 13,262 & 11,073 & 7,890 \\
\hline Common law & $\begin{array}{l}0.05^{* * *} \\
(0.004)\end{array}$ & $\begin{array}{c}\text { Panel D: Compl } \\
0.04^{* * *} \\
(0.007)\end{array}$ & $\begin{array}{c}\text { leted secondary sch } \\
0.04^{* * *} \\
(0.007)\end{array}$ & $\begin{array}{l}\text { ooling } \\
0.04^{* * *} \\
(0.011)\end{array}$ & $\begin{array}{l}0.02^{* * *} \\
(0.006)\end{array}$ \\
\hline Observations & 16,319 & 15,081 & 13,262 & 11,073 & 7,890 \\
\hline \multicolumn{6}{|c|}{$\begin{array}{c}\text { Geographic controls } \\
\text { Panel } \boldsymbol{E}: \text { Years of education }\end{array}$} \\
\hline Common law & $\begin{array}{l}1.53^{* * *} \\
(0.486)\end{array}$ & $\begin{array}{l}1.24^{* * *} \\
(0.443)\end{array}$ & $\begin{array}{c}1.27^{* *} \\
(0.505)\end{array}$ & $\begin{array}{c}1.25^{* *} \\
(0.612)\end{array}$ & $\begin{array}{l}1.17^{* * *} \\
(0.445)\end{array}$ \\
\hline Observations & 16,232 & 15,019 & 13,221 & 11,032 & 7,850 \\
\hline \multicolumn{6}{|c|}{ Panel F: Completed one year of schooling } \\
\hline Common law & $\begin{array}{l}0.20^{* * *} \\
(0.067)\end{array}$ & $\begin{array}{l}0.18^{* * *} \\
(0.065)\end{array}$ & $\begin{array}{l}0.18^{* * *} \\
(0.070)\end{array}$ & $\begin{array}{c}0.18^{* *} \\
(0.080)\end{array}$ & $\begin{array}{l}0.18^{* * *} \\
(0.069)\end{array}$ \\
\hline Observations & 16,232 & 15,019 & 13,221 & 11,032 & 7,850 \\
\hline \multicolumn{6}{|c|}{ Panel G: Completed primary schooling } \\
\hline Common law & $\begin{array}{l}0.10^{* * *} \\
(0.028)\end{array}$ & $\begin{array}{l}0.08^{* * *} \\
(0.021)\end{array}$ & $\begin{array}{c}0.09^{* * *} \\
(0.025)\end{array}$ & $\begin{array}{c}0.08^{* *} \\
(0.033)\end{array}$ & $\begin{array}{l}0.07^{* * *} \\
(0.018)\end{array}$ \\
\hline Observations & 16,244 & 15,031 & 13,232 & 11,043 & 7,860 \\
\hline Common law & $\begin{array}{l}0.04^{* * *} \\
(0.005)\end{array}$ & $\begin{array}{c}\text { Panel H: Comp } \\
0.03^{* * *} \\
(0.006)\end{array}$ & $\begin{array}{c}\text { leted secondary sch } \\
0.03^{* * *} \\
(0.008)\end{array}$ & $\begin{array}{c}\text { ooling } \\
0.03^{* *} \\
(0.013)\end{array}$ & $\begin{array}{l}0.02^{* * *} \\
(0.005)\end{array}$ \\
\hline Observations & 16,244 & 15,031 & 13,232 & 11,043 & 7,860 \\
\hline Ethnic homeland FE & $\checkmark$ & $\checkmark$ & $\checkmark$ & $\checkmark$ & $\checkmark$ \\
\hline Cohort of birth FE & $\checkmark$ & $\checkmark$ & $\checkmark$ & $\checkmark$ & $\checkmark$ \\
\hline Religion FE & $\checkmark$ & $\checkmark$ & $\checkmark$ & $\checkmark$ & $\checkmark$ \\
\hline Age controls & $\checkmark$ & $\checkmark$ & $\checkmark$ & $\checkmark$ & $\checkmark$ \\
\hline
\end{tabular}


Table 4: Average effects: Legal origins, female employment, and marriage

\begin{tabular}{|c|c|c|c|c|c|}
\hline & \multirow[b]{2}{*}{$\begin{array}{c}\text { OLS } \\
(1)\end{array}$} & \multicolumn{4}{|c|}{ RDD - Bandwidth } \\
\hline & & $\begin{array}{l}<250 \mathrm{~km} \text { of bound. } \\
(2)\end{array}$ & $\begin{array}{l}<150 \mathrm{~km} \text { of bound. } \\
\text { (3) }\end{array}$ & $\begin{array}{l}<100 \mathrm{~km} \text { of bound. } \\
(4)\end{array}$ & $\begin{array}{l}<60 \mathrm{~km} \text { of bound. } \\
(5)\end{array}$ \\
\hline \multicolumn{6}{|c|}{ Baseline specification } \\
\hline Common law & $\begin{array}{c}0.19 \\
(0.203)\end{array}$ & $\begin{array}{c}0.21 \\
(0.192)\end{array}$ & $\begin{array}{c}0.24 \\
(0.190)\end{array}$ & $\begin{array}{c}0.26 \\
(0.196)\end{array}$ & $\begin{array}{c}0.24 \\
(0.200)\end{array}$ \\
\hline Observations & 16,319 & 15,081 & 13,262 & 11,073 & 7,890 \\
\hline \multicolumn{6}{|c|}{ Panel B: Work in professional sector } \\
\hline Common law & $\begin{array}{l}0.0130^{* * *} \\
(0.003)\end{array}$ & $\begin{array}{l}0.0086^{* * *} \\
(0.003)\end{array}$ & $\begin{array}{l}0.0093^{* * *} \\
(0.003)\end{array}$ & $\begin{array}{l}0.0111^{* *} \\
(0.004)\end{array}$ & $\begin{array}{l}0.0055 \\
(0.008)\end{array}$ \\
\hline Observations & 16,319 & 15,081 & 13,262 & 11,073 & 7,890 \\
\hline \multicolumn{6}{|c|}{ Panel C: Early marriage (before age 16) } \\
\hline Common law & $\begin{array}{l}-0.03 \\
(0.034)\end{array}$ & $\begin{array}{l}-0.03 \\
(0.036)\end{array}$ & $\begin{array}{l}-0.03 \\
(0.034)\end{array}$ & $\begin{array}{c}-0.03 \\
(0.036)\end{array}$ & $\begin{array}{l}-0.03 \\
(0.026)\end{array}$ \\
\hline Observations & 14,787 & 13,714 & 11,959 & 9,857 & 6,983 \\
\hline \multicolumn{6}{|c|}{ Panel D: Early marriage (before age 18) } \\
\hline Common law & $\begin{array}{l}-0.08^{* * *} \\
(0.019)\end{array}$ & $\begin{array}{l}-0.08^{* * *} \\
(0.023)\end{array}$ & $\begin{array}{l}-0.08 * * * \\
(0.021)\end{array}$ & $\begin{array}{l}-0.06^{* * *} \\
(0.023)\end{array}$ & $\begin{array}{l}-0.04^{* * *} \\
(0.012)\end{array}$ \\
\hline Observations & 14,787 & 13,714 & 11,959 & 9,857 & 6,983 \\
\hline \multicolumn{6}{|c|}{ Panel E: Partner age gap (Male-female) } \\
\hline Common law & $\begin{array}{c}1.57 \\
(1.081)\end{array}$ & $\begin{array}{c}1.48 \\
(1.145)\end{array}$ & $\begin{array}{c}1.46 \\
(1.158)\end{array}$ & $\begin{array}{c}1.36 \\
(1.165)\end{array}$ & $\begin{array}{c}1.73^{* *} \\
(0.879)\end{array}$ \\
\hline Observations & 13,107 & 12,198 & 10,613 & 8,724 & 6,160 \\
\hline \multicolumn{6}{|c|}{$\begin{array}{l}\text { Geographic controls } \\
\text { Panel F: Respondent is working }\end{array}$} \\
\hline Common law & $\begin{array}{c}0.25 \\
(0.157)\end{array}$ & $\begin{array}{c}0.26 \\
(0.181)\end{array}$ & $\begin{array}{c}0.26 \\
(0.185)\end{array}$ & $\begin{array}{c}0.27 \\
(0.195)\end{array}$ & $\begin{array}{c}0.23 \\
(0.187)\end{array}$ \\
\hline Observations & 16,244 & 15,031 & 13,232 & 11,043 & 7,860 \\
\hline \multicolumn{6}{|c|}{ Panel G: Work in professional sector } \\
\hline Common law & $\begin{array}{l}0.0110^{* * *} \\
(0.002)\end{array}$ & $\begin{array}{l}0.0092^{* *} \\
(0.004)\end{array}$ & $\begin{array}{l}0.0101^{* *} \\
(0.005)\end{array}$ & $\begin{array}{l}0.0117^{*} \\
(0.006)\end{array}$ & $\begin{array}{l}0.0054 \\
(0.008)\end{array}$ \\
\hline Observations & 16,244 & 15,031 & 13,232 & 11,043 & 7,860 \\
\hline \multicolumn{6}{|c|}{ Panel H: Early marriage (before age 16) } \\
\hline Common law & $\begin{array}{c}-0.02 \\
(0.048)\end{array}$ & $\begin{array}{c}-0.02 \\
(0.034)\end{array}$ & $\begin{array}{l}-0.04 \\
(0.029)\end{array}$ & $\begin{array}{l}-0.03 \\
(0.034)\end{array}$ & $\begin{array}{r}-0.04^{*} \\
(0.025)\end{array}$ \\
\hline Observations & 14,719 & 13,670 & 11,935 & 9,833 & 6,959 \\
\hline \multicolumn{6}{|c|}{ Panel I: Early marriage (before age 18) } \\
\hline Common law & $\begin{array}{r}-0.06^{*} \\
(0.033)\end{array}$ & $\begin{array}{l}-0.06^{* *} \\
(0.023)\end{array}$ & $\begin{array}{l}-0.07^{* * *} \\
(0.022)\end{array}$ & $\begin{array}{l}-0.06^{* *} \\
(0.025)\end{array}$ & $\begin{array}{l}-0.04^{* * *} \\
(0.011)\end{array}$ \\
\hline Observations & 14,719 & 13,670 & 11,935 & 9,833 & 6,959 \\
\hline \multicolumn{6}{|c|}{ Panel J: Partner age gap (Male-female) } \\
\hline Common law & $\begin{array}{c}1.51 \\
(1.180)\end{array}$ & $\begin{array}{c}1.47 \\
(1.084)\end{array}$ & $\begin{array}{c}1.51 \\
(1.126)\end{array}$ & $\begin{array}{c}1.44 \\
(1.087)\end{array}$ & $\begin{array}{c}1.71^{* *} \\
(0.798)\end{array}$ \\
\hline Observations & 13,050 & 12,161 & 10,594 & 8,705 & 6,141 \\
\hline Ethnic homeland FE & $\checkmark$ & $\checkmark$ & $\checkmark$ & $\checkmark$ & $\checkmark$ \\
\hline Age FE & $\checkmark$ & $\checkmark$ & $\checkmark$ & $\checkmark$ & $\checkmark$ \\
\hline Year of birth FE & $\checkmark$ & $\checkmark$ & $\checkmark$ & $\checkmark$ & $\checkmark$ \\
\hline Religion FE & $\checkmark$ & $\checkmark$ & $\checkmark$ & $\checkmark$ & $\checkmark$ \\
\hline Geographic controls & $\checkmark$ & $\checkmark$ & $\checkmark$ & $\checkmark$ & $\checkmark$ \\
\hline
\end{tabular}


Table 5: Heterogeneity: Ancestral norms, legal origins and female education

\begin{tabular}{|c|c|c|c|c|c|c|}
\hline & \multicolumn{2}{|c|}{ Female participation in agri. } & \multicolumn{2}{|c|}{ Bride Price } & \multicolumn{2}{|c|}{ Patrilocality } \\
\hline & $\begin{array}{c}(1) \\
(\mathrm{No})\end{array}$ & $\begin{array}{c}(2) \\
\text { (Yes) }\end{array}$ & $\begin{array}{c}(3) \\
(\mathrm{No})\end{array}$ & $\begin{array}{c}(4) \\
(\text { Yes })\end{array}$ & $\begin{array}{l}(5) \\
(\mathrm{No})\end{array}$ & $\begin{array}{c}(6) \\
\text { (Yes) }\end{array}$ \\
\hline \multicolumn{7}{|c|}{ Panel A: Years of education } \\
\hline Common law & $\begin{array}{l}0.89^{* * *} \\
(0.165)\end{array}$ & $\begin{array}{l}2.51^{* * *} \\
(0.132)\end{array}$ & $\begin{array}{l}2.57^{* * *} \\
(0.064)\end{array}$ & $\begin{array}{c}0.70^{* * *} \\
(0.176)\end{array}$ & $\begin{array}{l}2.56^{* * *} \\
(0.059)\end{array}$ & $\begin{array}{c}0.72^{* * *} \\
(0.177)\end{array}$ \\
\hline Observations & 2,333 & 4,239 & 2,498 & 4,405 & 2,388 & 4,405 \\
\hline \multicolumn{7}{|c|}{ Panel B: Completed one year of schooling } \\
\hline Common law & $\begin{array}{c}0.16^{* * *} \\
(0.016)\end{array}$ & $\begin{array}{c}0.39^{* * *} \\
(0.015)\end{array}$ & $\begin{array}{l}0.40^{* * * *} \\
(0.004)\end{array}$ & $\begin{array}{l}0.10^{* * *} \\
(0.025)\end{array}$ & $\begin{array}{l}0.40^{* * *} \\
(0.003)\end{array}$ & $\begin{array}{c}0.10^{* * *} \\
(0.025)\end{array}$ \\
\hline Observations & 2,333 & 4,239 & 2,498 & 4,405 & 2,388 & 4,405 \\
\hline \multicolumn{7}{|c|}{ Panel C: Completed primary schooling } \\
\hline Common law & $\begin{array}{l}0.10^{* * *} \\
(0.012)\end{array}$ & $\begin{array}{l}0.15^{* * *} \\
(0.011)\end{array}$ & $\begin{array}{c}0.14^{* * *} \\
(0.005)\end{array}$ & $\begin{array}{c}0.07^{* * *} \\
(0.021)\end{array}$ & $\begin{array}{l}0.14^{* * *} \\
(0.007)\end{array}$ & $\begin{array}{c}0.08^{* * * *} \\
(0.021)\end{array}$ \\
\hline Observations & 2,334 & 4,248 & 2,498 & 4,415 & 2,388 & 4,415 \\
\hline \multicolumn{7}{|c|}{ Panel D: Completed secondary schooling } \\
\hline Common law & $\begin{array}{c}0.01^{*} \\
(0.008)\end{array}$ & $\begin{array}{l}0.04^{* * *} \\
(0.010)\end{array}$ & $\begin{array}{l}0.04^{* * *} \\
(0.001)\end{array}$ & $\begin{array}{c}0.02^{* *} \\
(0.009)\end{array}$ & $\begin{array}{l}0.04^{* * *} \\
(0.002)\end{array}$ & $\begin{array}{c}0.02^{* * * *} \\
(0.008)\end{array}$ \\
\hline Observations & 2,334 & 4,248 & 2,498 & 4,415 & 2,388 & 4,415 \\
\hline Ethnic homeland FE & $\checkmark$ & $\checkmark$ & $\checkmark$ & $\checkmark$ & $\checkmark$ & $\checkmark$ \\
\hline Age FE & $\checkmark$ & $\checkmark$ & $\checkmark$ & $\checkmark$ & $\checkmark$ & $\checkmark$ \\
\hline Year of birth FE & $\checkmark$ & $\checkmark$ & $\checkmark$ & $\checkmark$ & $\checkmark$ & $\checkmark$ \\
\hline Religion FE & $\checkmark$ & $\checkmark$ & $\checkmark$ & $\checkmark$ & $\checkmark$ & $\checkmark$ \\
\hline Geographic controls & $\checkmark$ & $\checkmark$ & $\checkmark$ & $\checkmark$ & $\checkmark$ & $\checkmark$ \\
\hline
\end{tabular}

Note: In each specification we restrict the analysis to observations within $60 \mathrm{~km}$ of the border and we control for a secondorder polynomial in the distance from the centroid of each pixel to the nearest national border with different legal origins. Robust standard errors, adjusted for double-clustering at the country and the ethno-linguistic family level using the approach of (Cameron et al., 2011), are in parenthesis. Geographic controls include area under water, elevation, soil suitability for agriculture, natural resources, distance to the sea coast, distance to the national border, and area of the country-ethnic homeland. Age controls include indicators for respondent's age and age squared. Coefficients that are significantly different from zero are denoted by the following system: ${ }^{* *} p<0.01,{ }^{*} p<0.05,{ }^{*} p<0.1$. 
Table 6: Heterogeneity: Ancestral norms, legal origins, female employment and marriage

\begin{tabular}{|c|c|c|c|c|c|c|}
\hline & \multicolumn{2}{|c|}{ Female participation in agri. } & \multicolumn{2}{|c|}{ Bride Price } & \multicolumn{2}{|c|}{ Patrilocality } \\
\hline & $\begin{array}{l}(1) \\
(\mathrm{No})\end{array}$ & $\begin{array}{c}(2) \\
(\text { Yes) }\end{array}$ & $\begin{array}{l}(3) \\
(\mathrm{No})\end{array}$ & $\begin{array}{c}(4) \\
(\text { Yes) }\end{array}$ & $\begin{array}{l}(5) \\
(\mathrm{No})\end{array}$ & $\begin{array}{c}(6) \\
(\text { Yes })\end{array}$ \\
\hline \multicolumn{7}{|c|}{ Panel A: Work in the professional sector } \\
\hline Common law & $\begin{array}{r}-0.0046 \\
(0.008)\end{array}$ & $\begin{array}{l}0.0147^{* *} \\
(0.007)\end{array}$ & $\begin{array}{l}0.0145^{*>} \\
(0.003)\end{array}$ & $\begin{array}{l}* 0.0000 \\
(0.008)\end{array}$ & $\begin{array}{l}0.0130^{* * *} \\
(0.004)\end{array}$ & $\begin{array}{l}* 0.0005 \\
(0.008)\end{array}$ \\
\hline Observations & 2,334 & 4,248 & 2,498 & 4,415 & 2,388 & 4,415 \\
\hline \multicolumn{7}{|c|}{ Panel B: Early marriage (before age 16) } \\
\hline Common law & $\begin{array}{c}-0.00 \\
(0.018)\end{array}$ & $\begin{array}{l}-0.11^{* * *} \\
(0.013)\end{array}$ & $\begin{array}{l}-0.11^{* *} \\
(0.021)\end{array}$ & $\begin{array}{c}0.02 \\
(0.018)\end{array}$ & $\begin{array}{l}-0.10^{* * *} \\
(0.008)\end{array}$ & $\begin{array}{c}0.02 \\
(0.017)\end{array}$ \\
\hline Observations & 2,287 & 3,523 & 2,413 & 3,690 & 2,303 & 3,690 \\
\hline \multicolumn{7}{|c|}{ Panel C: Early marriage (before age 18) } \\
\hline Common law & $\begin{array}{c}-0.04 \\
(0.032)\end{array}$ & $\begin{array}{l}-0.03^{* * *} \\
(0.009)\end{array}$ & $\begin{array}{c}-0.05^{*} \\
(0.028)\end{array}$ & $\begin{array}{l}-0.03 \\
(0.029)\end{array}$ & $\begin{array}{l}-0.04^{* *} \\
(0.017)\end{array}$ & $\begin{array}{c}-0.03 \\
(0.029)\end{array}$ \\
\hline Observations & 2,287 & 3,523 & 2,413 & 3,690 & 2,303 & 3,690 \\
\hline \multicolumn{7}{|c|}{ Panel D: Partner age gap (Male-female) } \\
\hline Common law & $\begin{array}{l}2.67^{* * *} \\
(0.445)\end{array}$ & $\begin{array}{l}-0.69^{* *} \\
(0.282)\end{array}$ & $\begin{array}{l}-0.43^{* *} \\
(0.099)\end{array}$ & $\begin{array}{l}2.80^{* * * *} \\
(0.328)\end{array}$ & $\begin{array}{l}-0.43^{* * *} \\
(0.067)\end{array}$ & $\begin{array}{l}2.86^{* * *} \\
(0.346)\end{array}$ \\
\hline Observations & 2,174 & 2,993 & 2,039 & 3,358 & 1,949 & 3,360 \\
\hline Ethnic homeland FE & $\checkmark$ & $\checkmark$ & $\checkmark$ & $\checkmark$ & $\checkmark$ & $\checkmark$ \\
\hline Cohort of birth FE & $\checkmark$ & $\checkmark$ & $\checkmark$ & $\checkmark$ & $\checkmark$ & $\checkmark$ \\
\hline Religion FE & $\checkmark$ & $\checkmark$ & $\checkmark$ & $\checkmark$ & $\checkmark$ & $\checkmark$ \\
\hline Geographic controls & $\checkmark$ & $\checkmark$ & $\checkmark$ & $\checkmark$ & $\checkmark$ & $\checkmark$ \\
\hline Age controls & $\checkmark$ & $\checkmark$ & $\checkmark$ & $\checkmark$ & $\checkmark$ & $\checkmark$ \\
\hline
\end{tabular}

Note: In each specification we restrict the analysis to observations within $60 \mathrm{~km}$ of the border and we control for a secondorder polynomial in the distance from the centroid of each pixel to the nearest national border with different legal origins. Robust standard errors, adjusted for double-clustering at the country and the ethno-linguistic family level using the approach of (Cameron et al., 2011), are in parenthesis. Geographic controls include area under water, elevation, soil suitability for agriculture, natural resources, distance to the sea coast, distance to the national border, and area of the country-ethnic homeland. Age controls include indicators for respondent's age and age squared. Coefficients that are significantly different from zero are denoted by the following system: ${ }^{* * *} p<0.01,{ }^{* *} p<0.05,{ }^{*} p<0.1$. 


\section{Appendix NOT FOR PUBLICATION}

Table A1: Countries, DHS surveys, and legal origins

\begin{tabular}{lcc}
\hline Countries & DHS year of surveys & Legal Origins \\
\hline Benin & $1996,2001,2011-12,2017-18$ & Civil law \\
Burkina Faso & $1993,1998-99,2003,2010$ & Civil law \\
Cameroon & $1991,2004,2011$ & Civil law \\
Cote d'Ivoire & $1994,1998-99,2011-12$ & Civil law \\
Ethiopia & $2000,2005,2011,2016$ & Civil law \\
Ghana & $1993,1998,2003,2008,2014$ & Common law \\
Guinea & $1999,2005,2012$ & Civil law \\
Kenya & $2003,2008-09,2014$ & Common law \\
Liberia & 1986,2013 & Common law \\
Malawi & $2000,2004,2010,2015$ & Common law \\
Mozambique & 2011 & Civil law \\
Namibia & $2000,2006-07,2013$ & Common law \\
Niger & 1992,1998 & Civil law \\
Nigeria & 2008,2013 & Common law \\
Sierra Leone & 2008,2013 & Common law \\
Togo & $1988,1998,2013-14$ & Civil law \\
Uganda & 2011,2016 & Common law \\
Zaire & $2007,2013-14$ & Civil law \\
Zambia & $2007,2013-14$ & Common law \\
\hline
\end{tabular}


Table A2: Robustness check - Third order polynomial: legal origins and female education

\begin{tabular}{|c|c|c|c|c|c|}
\hline & \multicolumn{5}{|c|}{ RDD - Bandwidth } \\
\hline & $\begin{array}{l}\text { OLS } \\
(1)\end{array}$ & $\begin{array}{c}<250 \mathrm{~km} \text { of bound. } \\
(2)\end{array}$ & $<150 \mathrm{~km}$ of bound. & $<100 \mathrm{~km}$ of bound. & $<60 \mathrm{~km}$ of bound \\
\hline Common law & $\begin{array}{l}1.53^{* * *} \\
(0.486)\end{array}$ & $\begin{array}{l}\text { Panel A: } \\
1.26^{* * *} \\
(0.463)\end{array}$ & $\begin{array}{c}\text { Years of education } \\
1.26^{* *} \\
(0.530)\end{array}$ & $\begin{array}{c}1.27^{* *} \\
(0.586)\end{array}$ & $\begin{array}{l}1.17^{* * *} \\
(0.441)\end{array}$ \\
\hline Observations & 16,232 & 15,019 & 13,221 & 11,032 & 7,850 \\
\hline \multicolumn{6}{|c|}{ Panel B: Has at least one year of education } \\
\hline Common law & $\begin{array}{l}0.20^{* * *} \\
(0.067)\end{array}$ & $\begin{array}{l}0.18^{* * *} \\
(0.067)\end{array}$ & $\begin{array}{c}0.18^{* *} \\
(0.073)\end{array}$ & $\begin{array}{c}0.18^{* *} \\
(0.078)\end{array}$ & $\begin{array}{l}0.18^{* * *} \\
(0.069)\end{array}$ \\
\hline Observations & 16,232 & 15,019 & 13,221 & 11,032 & 7,850 \\
\hline Common law & $\begin{array}{l}0.10^{* * *} \\
(0.028)\end{array}$ & $\begin{array}{c}\text { Panel C: Has a } \\
0.09^{* * *} \\
(0.022)\end{array}$ & $\begin{array}{c}\text { least primary edu } \\
0.08^{* * *} \\
(0.027)\end{array}$ & $\begin{array}{c}\text { cation } \\
0.08^{* * *} \\
(0.031)\end{array}$ & $\begin{array}{l}0.07^{* * *} \\
(0.017)\end{array}$ \\
\hline Observations & 16,244 & 15,031 & 13,232 & 11,043 & 7,860 \\
\hline \multicolumn{6}{|c|}{ Panel D: Has at least secondary education } \\
\hline Common law & $\begin{array}{l}0.04^{* * *} \\
(0.005)\end{array}$ & $\begin{array}{l}0.03^{* * *} \\
(0.007)\end{array}$ & $\begin{array}{l}0.03^{* * *} \\
(0.009)\end{array}$ & $\begin{array}{c}0.03^{* *} \\
(0.012)\end{array}$ & $\begin{array}{l}0.02^{* * *} \\
(0.004)\end{array}$ \\
\hline Observations & 16,244 & 15,031 & 13,232 & 11,043 & 7,860 \\
\hline Ethnic homeland FE & $\checkmark$ & $\checkmark$ & $\checkmark$ & $\checkmark$ & $\checkmark$ \\
\hline Cohort of birth FE & $\checkmark$ & $\checkmark$ & $\checkmark$ & $\checkmark$ & $\checkmark$ \\
\hline Religion FE & $\checkmark$ & $\checkmark$ & $\checkmark$ & $\checkmark$ & $\checkmark$ \\
\hline Geographic controls & $\checkmark$ & $\checkmark$ & $\checkmark$ & $\checkmark$ & $\checkmark$ \\
\hline Age controls & $\checkmark$ & $\checkmark$ & $\checkmark$ & $\checkmark$ & $\checkmark$ \\
\hline
\end{tabular}

Note: Specifications in columns (2)-(5) control for a third-order polynomial in the distance from the centroid of each pixel to the nearest national border with different legal origins. Robust standard errors, adjusted for double-clustering at the country and the ethno-linguistic family level using the approach of (Cameron et al., 2011), are in parenthesis. Geographic controls include area under water, elevation, soil suitability for agriculture, natural resources, distance to the sea coast, distance to the national border, and area of the country-ethnic homeland. Age controls include indicators for respondent's age and age squared. Coefficients that are significantly different from zero are denoted by the following system: ${ }^{* * *} p<0.01,{ }^{* *} p<0.05,{ }^{*} p<0.1$. 
Table A3: Robustness check - Polynomial in latitude-longitude: legal origins and female education

\begin{tabular}{|c|c|c|c|c|c|}
\hline & \multicolumn{5}{|c|}{ RDD - Bandwidth } \\
\hline & $\begin{array}{l}\text { OLS } \\
(1)\end{array}$ & $\begin{array}{c}<250 \mathrm{~km} \text { of bound. } \\
(2)\end{array}$ & $\begin{array}{l}<150 \mathrm{~km} \text { of bound. } \\
(3)\end{array}$ & $\begin{array}{c}<100 \mathrm{~km} \text { of bound. } \\
(4)\end{array}$ & $\begin{array}{c}<60 \mathrm{~km} \text { of bound. } \\
(5)\end{array}$ \\
\hline \multicolumn{6}{|c|}{ Panel A: Years of education } \\
\hline Common law & $\begin{array}{r}1.06^{*} \\
(0.589)\end{array}$ & $\begin{array}{c}0.94^{* *} \\
(0.464)\end{array}$ & $\begin{array}{r}1.02^{*} \\
(0.545)\end{array}$ & $\begin{array}{r}1.14^{*} \\
(0.612)\end{array}$ & $\begin{array}{l}1.46^{* * *} \\
(0.540)\end{array}$ \\
\hline Observations & 16,232 & 15,019 & 13,221 & 11,032 & 7,850 \\
\hline \multicolumn{6}{|c|}{ Panel B: Has at least one year of education } \\
\hline Common law & $\begin{array}{c}0.17^{* *} \\
(0.079)\end{array}$ & $\begin{array}{c}0.17^{* *} \\
(0.074)\end{array}$ & $\begin{array}{c}0.18^{* *} \\
(0.080)\end{array}$ & $\begin{array}{c}0.20^{* *} \\
(0.084)\end{array}$ & $\begin{array}{l}0.25^{* * *} \\
(0.084)\end{array}$ \\
\hline Observations & 16,232 & 15,019 & 13,221 & 11,032 & 7,850 \\
\hline \multicolumn{6}{|c|}{ Panel C: Has at least primary education } \\
\hline Common law & $\begin{array}{r}0.06^{*} \\
(0.032)\end{array}$ & $\begin{array}{c}0.06^{* *} \\
(0.024)\end{array}$ & $\begin{array}{c}0.06^{* *} \\
(0.026)\end{array}$ & $\begin{array}{c}0.08^{* * *} \\
(0.031)\end{array}$ & $\begin{array}{l}0.09^{* * *} \\
(0.015)\end{array}$ \\
\hline Observations & 16,244 & 15,031 & 13,232 & 11,043 & 7,860 \\
\hline \multicolumn{6}{|c|}{ Panel D: Has at least secondary education } \\
\hline Common law & $\begin{array}{c}0.01 \\
(0.009)\end{array}$ & $\begin{array}{c}0.02 \\
(0.012)\end{array}$ & $\begin{array}{c}0.02 \\
(0.014)\end{array}$ & $\begin{array}{c}0.01 \\
(0.018)\end{array}$ & $\begin{array}{c}0.01 \\
(0.009)\end{array}$ \\
\hline Observations & 16,244 & 15,031 & 13,232 & 11,043 & 7,860 \\
\hline Ethnic homeland FE & $\checkmark$ & $\checkmark$ & $\checkmark$ & $\checkmark$ & $\checkmark$ \\
\hline Cohort of birth FE & $\checkmark$ & $\checkmark$ & $\checkmark$ & $\checkmark$ & $\checkmark$ \\
\hline Religion FE & $\checkmark$ & $\checkmark$ & $\checkmark$ & $\checkmark$ & $\checkmark$ \\
\hline Geographic controls & $\checkmark$ & $\checkmark$ & $\checkmark$ & $\checkmark$ & $\checkmark$ \\
\hline Age controls & $\checkmark$ & $\checkmark$ & $\checkmark$ & $\checkmark$ & $\checkmark$ \\
\hline
\end{tabular}


Table A4: Heterogeneity by birth cohort

\begin{tabular}{|c|c|c|c|c|}
\hline & \multicolumn{2}{|c|}{$<250 \mathrm{~km}$ of bound. } & \multicolumn{2}{|c|}{$<60 \mathrm{~km}$ of bound. } \\
\hline & $\begin{array}{c}(1) \\
{[19481976]}\end{array}$ & $\begin{array}{c}(2) \\
{[1977 \text { 1994] }}\end{array}$ & $\begin{array}{c}(3) \\
{[1948 \text { 1976] }}\end{array}$ & $\begin{array}{c}(4) \\
{[1977 \text { 1994] }}\end{array}$ \\
\hline \multicolumn{5}{|c|}{ Panel A: Years of education } \\
\hline Common law & $\begin{array}{c}0.75^{* *} \\
(0.321)\end{array}$ & $\begin{array}{l}2.20^{* * *} \\
(0.429)\end{array}$ & $\begin{array}{c}0.84^{* * *} \\
(0.311)\end{array}$ & $\begin{array}{l}2.03^{* * *} \\
(0.470)\end{array}$ \\
\hline Observations & 7,688 & 7,331 & 4,337 & 3,513 \\
\hline \multicolumn{5}{|c|}{ Panel B: Has at least one year of education } \\
\hline Common law & $\begin{array}{l}0.110^{* *} \\
(0.051)\end{array}$ & $\begin{array}{l}0.286^{* * *} \\
(0.079)\end{array}$ & $\begin{array}{c}0.111^{* *} \\
(0.045)\end{array}$ & $\begin{array}{l}0.291^{* * *} \\
(0.087)\end{array}$ \\
\hline Observations & 7,688 & 7,331 & 4,337 & 3,513 \\
\hline \multicolumn{5}{|c|}{ Panel C: Has at least primary education } \\
\hline Common law & $\begin{array}{l}0.055^{* * *} \\
(0.018)\end{array}$ & $\begin{array}{l}0.150^{* * *} \\
(0.011)\end{array}$ & $\begin{array}{c}0.062^{* *} \\
(0.028)\end{array}$ & $\begin{array}{l}0.121^{* * *} \\
(0.012)\end{array}$ \\
\hline Observations & 7,697 & 7,334 & 4,344 & 3,516 \\
\hline \multicolumn{5}{|c|}{ Panel D: Has at least secondary education } \\
\hline Common law & $\begin{array}{c}0.007 \\
(0.009)\end{array}$ & $\begin{array}{l}0.057^{* * *} \\
(0.004)\end{array}$ & $\begin{array}{c}0.005 \\
(0.004)\end{array}$ & $\begin{array}{l}0.043^{* * *} \\
(0.010)\end{array}$ \\
\hline Observations & 7,697 & 7,334 & 4,344 & 3,516 \\
\hline Ethnic homeland FE & $\checkmark$ & $\checkmark$ & $\checkmark$ & $\checkmark$ \\
\hline Cohort of birth FE & $\checkmark$ & $\checkmark$ & $\checkmark$ & $\checkmark$ \\
\hline Religion FE & $\checkmark$ & $\checkmark$ & $\checkmark$ & $\checkmark$ \\
\hline Geographic controls & $\checkmark$ & $\checkmark$ & $\checkmark$ & $\checkmark$ \\
\hline Age controls & $\checkmark$ & $\checkmark$ & $\checkmark$ & $\checkmark$ \\
\hline
\end{tabular}

Note: In each specification we restrict the analysis to observations within $60 \mathrm{Km}$ of the border and we control for a second-order polynomial in the distance from the centroid of each pixel to the nearest national border with different legal origin. Robust standard errors, adjusted for double-clustering at the country and the ethno-linguistic family level using the approach of (Cameron et al., 2011), are in parenthesis. Geographic controls include area under water, elevation, soil suitability for agriculture, natural resources, distance to the sea coast, distance to the national border, and area of the country-ethnic homeland. Age controls include indicators for respondent's age and age squared. Coefficients that are significantly different from zero are denoted by the following system: ${ }^{* * *} p<0.01,{ }^{* *} p<0.05,{ }^{*} p<0.1$. 
Table A5: Female education and ancestral norms

\begin{tabular}{lcccccc}
\hline & \multicolumn{5}{c}{ Years of education } \\
\cline { 2 - 7 } & $(1)$ & $(2)$ & $(3)$ & $(4)$ & $(5)$ & $(6)$ \\
\hline Female Partiticaption in Agri. & $2.99^{* * *}$ & $2.96^{* * *}$ \\
Bride Price & $(0.065)$ & $(0.064)$ & & & \\
Patrilocality & & & $-0.74^{* * *}$ & $-0.72^{* * *}$ \\
& & $(0.064)$ & $(0.062)$ & \\
Observations & & & & $-1.14^{* * *}$ & $-1.11^{* * *}$ \\
\hline Age controls & & & & $(0.069)$ & $(0.067)$ \\
\hline
\end{tabular}

Note: In this table we report results from a simple OLS specification where we regress the respondent's number of years of education on a variable that indicates the ancestral norm of his ethnic group. Robust standard errors are in parenthesis. We control for the respondent's age and age squared. Coefficients that are significantly different from zero are denoted by the following system: ${ }^{* *} p<0.01,{ }^{* *} p<0.05,{ }^{*} p<0.1$. 
Table A6: Ancestral norms, legal origins, and female education (specification with interaction term)

\begin{tabular}{|c|c|c|c|c|c|c|}
\hline & \multicolumn{2}{|c|}{ Female participation in agri. } & \multicolumn{2}{|c|}{ Bride Price } & \multicolumn{2}{|c|}{ Patrilocality } \\
\hline & (1) & $(2)$ & (3) & (4) & (5) & (6) \\
\hline \multicolumn{7}{|c|}{ Panel A: Years of education } \\
\hline Common law & $0.55^{* * *}$ & $0.50^{*}$ & $2.48^{* * *}$ & $2.45^{* * *}$ & $2.48^{* * *}$ & $2.43^{* * *}$ \\
\hline & $(0.090)$ & $(0.259)$ & $(0.058)$ & $(0.235)$ & $(0.064)$ & $(0.268)$ \\
\hline Common law x Culture & $1.96^{* * *}$ & $1.93^{* * *}$ & $-1.96^{* * *}$ & $*-2.02^{* * *}$ & $*-1.97^{* * *}$ & $*-1.97 * * *$ \\
\hline & $(0.127)$ & $(0.500)$ & $(0.150)$ & $(0.472)$ & $(0.155)$ & $(0.550)$ \\
\hline Observations & 12,489 & 12,439 & 13,541 & 13,491 & 12,902 & 12,852 \\
\hline \multicolumn{7}{|c|}{ Panel B: Has at least one year of education } \\
\hline Common law & $0.08^{* * *}$ & $0.08^{* *}$ & $0.34^{* * *}$ & $0.35^{* * *}$ & $0.34^{* * *}$ & $0.34^{* * *}$ \\
\hline & $(0.010)$ & $(0.030)$ & $(0.008)$ & $(0.027)$ & $(0.009)$ & $(0.032)$ \\
\hline Common law x Culture & $0.27^{* * *}$ & $0.27^{* * *}$ & $-0.27 * * *$ & $*-0.28 * * *$ & $*-0.27 * * *$ & $*-0.27 * * *$ \\
\hline & $(0.012)$ & $(0.060)$ & $(0.013)$ & $(0.055)$ & $(0.013)$ & $(0.064)$ \\
\hline Observations & 12,489 & 12,439 & 13,541 & 13,491 & 12,902 & 12,852 \\
\hline \multicolumn{7}{|c|}{ Panel C: Has at least primary education } \\
\hline Common law & $0.05^{* * *}$ & 0.04 & $0.15^{* * *}$ & $0.15^{* * *}$ & $0.15^{* * *}$ & $0.15^{* * *}$ \\
\hline & $(0.010)$ & $(0.035)$ & $(0.004)$ & $(0.028)$ & $(0.004)$ & $(0.031)$ \\
\hline Common law x Culture & $0.10^{* * *}$ & $0.11^{*}$ & $-0.09^{* * *}$ & ${ }^{*}-0.11^{*}$ & $-0.09^{* * *}$ & * $-0.11^{*}$ \\
\hline & $(0.012)$ & $(0.062)$ & $(0.014)$ & $(0.056)$ & $(0.014)$ & $(0.064)$ \\
\hline Observations & 12,500 & 12,450 & 13,553 & 13,503 & 12,914 & 12,864 \\
\hline \multicolumn{7}{|c|}{ Panel D: Has at least secondary education } \\
\hline Common law & $0.04^{* * *}$ & $0.02^{* *}$ & $0.03^{* * *}$ & $0.04^{* * *}$ & $0.03^{* * *}$ & $0.04^{* * *}$ \\
\hline & $(0.011)$ & $(0.009)$ & $(0.005)$ & $(0.008)$ & $(0.005)$ & $(0.009)$ \\
\hline Common law x Culture & -0.01 & 0.02 & 0.01 & -0.02 & 0.01 & -0.02 \\
\hline & $(0.008)$ & $(0.017)$ & $(0.007)$ & $(0.018)$ & $(0.008)$ & $(0.020)$ \\
\hline Observations & 12,500 & 12,450 & 13,553 & 13,503 & 12,914 & 12,864 \\
\hline Ethnic homeland FE & $\checkmark$ & $\checkmark$ & $\checkmark$ & $\checkmark$ & $\checkmark$ & $\checkmark$ \\
\hline Cohort of birth FE & $\checkmark$ & $\checkmark$ & $\checkmark$ & $\checkmark$ & $\checkmark$ & $\checkmark$ \\
\hline Religion FE & $\checkmark$ & $\checkmark$ & $\checkmark$ & $\checkmark$ & $\checkmark$ & $\checkmark$ \\
\hline Geographic controls & & $\checkmark$ & & $\checkmark$ & & $\checkmark$ \\
\hline Age controls & $\checkmark$ & $\checkmark$ & $\checkmark$ & $\checkmark$ & $\checkmark$ & $\checkmark$ \\
\hline
\end{tabular}

Note: In each specification we restrict the analysis to observations within $60 \mathrm{Km}$ of the border and we control for a secondorder polynomial in the distance from the centroid of each pixel to the nearest national border with different legal origin. Robust standard errors, adjusted for double-clustering at the country and the ethno-linguistic family level using the approach of (Cameron et al., 2011), are in parenthesis. Geographic controls include area under water, elevation, soil suitability for agriculture, natural resources, distance to the sea coast, distance to the national border, and area of the country-ethnic homeland. Age controls include indicators for respondent's age and age squared. Coefficients that are significantly different from zero are denoted by the following system: ${ }^{* * *} p<0.01,{ }^{* *} p<0.05,{ }^{*} p<0.1$. 
Table A7: Men - Ancestral norms, legal origins, and male education (specification with interaction term)

Female participation in agri. Bride Price Patrilocality (1)

\begin{tabular}{|c|c|c|c|}
\hline \multicolumn{4}{|c|}{ Panel A: Years of education } \\
\hline Common law & $\begin{array}{l}3.24^{* * *} \\
(0.136)\end{array}$ & $\begin{array}{c}-0.73 \\
(0.858)\end{array}$ & $\begin{array}{c}-0.76 \\
(0.852)\end{array}$ \\
\hline Common law x Culture & $\begin{array}{l}-1.22^{* * *} \\
(0.059)\end{array}$ & $\begin{array}{l}3.61^{\text {*** }} \\
(0.503)\end{array}$ & $\begin{array}{c}3.62^{* * *} \\
(0.506)\end{array}$ \\
\hline Observations & 2,653 & 2,823 & 2,752 \\
\hline \multicolumn{4}{|c|}{ Panel B: Has at least one year of education } \\
\hline Common law & $\begin{array}{l}0.25^{* * *} \\
(0.014)\end{array}$ & $\begin{array}{c}0.00 \\
(0.119)\end{array}$ & $\begin{array}{c}0.00 \\
(0.122)\end{array}$ \\
\hline Common law x Culture & $\begin{array}{l}-0.21^{* * *} \\
(0.001)\end{array}$ & $\begin{array}{l}0.19^{* * *} \\
(0.045)\end{array}$ & $\begin{array}{c}0.19^{* * *} \\
(0.046)\end{array}$ \\
\hline Observations & 2,653 & 2,823 & 2,752 \\
\hline \multicolumn{4}{|c|}{ Panel $C:$ Has at least primary education } \\
\hline Common law & $\begin{array}{c}0.31^{* * *} \\
(0.014)\end{array}$ & $\begin{array}{c}-0.00 \\
(0.081)\end{array}$ & $\begin{array}{c}-0.00 \\
(0.081)\end{array}$ \\
\hline Common law x Culture & $\begin{array}{l}-0.11^{* * * *} \\
(0.009)\end{array}$ & $\begin{array}{c}0.27^{* * *} \\
(0.050)\end{array}$ & $\begin{array}{l}0.27^{* * *} \\
(0.050)\end{array}$ \\
\hline Observations & 2,655 & 2,827 & 2,756 \\
\hline \multicolumn{4}{|c|}{ Panel D: Has at least secondary education } \\
\hline Common law & $\begin{array}{c}0.15^{* * *} \\
(0.012)\end{array}$ & $\begin{array}{c}-0.02 \\
(0.066)\end{array}$ & $\begin{array}{c}-0.02 \\
(0.066)\end{array}$ \\
\hline Common law x Culture & $\begin{array}{l}-0.09^{* * *} \\
(0.007)\end{array}$ & $\begin{array}{c}0.14^{* * *} \\
(0.036)\end{array}$ & $\begin{array}{l}0.14^{* * *} \\
(0.037)\end{array}$ \\
\hline Observations & 2,655 & 2,827 & 2,756 \\
\hline Ethnic homeland FE & $\checkmark$ & $\checkmark$ & $\checkmark$ \\
\hline Cohort of birth FE & $\checkmark$ & $\checkmark$ & $\checkmark$ \\
\hline Religion FE & $\checkmark$ & $\checkmark$ & $\checkmark$ \\
\hline Age controls & $\checkmark$ & $\checkmark$ & $\checkmark$ \\
\hline
\end{tabular}

Note: In each specification we restrict the analysis to observations within $60 \mathrm{Km}$ of the border and we control for a second-order polynomial in the distance from the centroid of each pixel to the nearest national border with different legal origin. Robust standard errors, adjusted for double-clustering at the country and the ethno-linguistic family level using the approach of (Cameron et al., 2011), are in parenthesis. Age controls include indicators for respondent's age and age squared. Coefficients that are significantly different from zero are denoted by the following system: ${ }^{* * *} p<0.01,{ }^{* *} p<0.05,{ }^{*} p<0.1$. 


\section{Data Appendix}

Light density at night: Light Density is calculated averaging light density observations across pixels that fall within the unit of analysis. We use the 2013 Nighttime Light (NTL) data (stable lights dataset) from the U.S. Air Forceâs Defense Meteorological Satellite Program/Operational Linescan System (DMSP/OLS). This dataset is made available by the U.S. National Oceanographic and Atmospheric Administration (NOAA). The pixel light (gain) values range from 0 to 63 with being the absence of light. Available at https://www.ngdc.noaa.gov/eog/dmsp/downloadV4composites

Population density: Population per sq. km. in 2000. Source: Nelson, Andy, 2004. African Population Database Documentation, UNEP GRID Sioux Falls. Available at https://www . arcgis . com/home/item. html?id=9ec46c83ca5c47ebb1a25bd43131b483

Elevation: Average elevation above sea level of each pixel. Source: National Oceanic and Atmospheric Administration (NOAA) and U.S. National Geophysical Data Center, TerrainBase, release 1.0 (CD-ROM), Boulder, Colorado. Available at http://nelson .wisc.edu/sage/data-and-models/atlas/data.php?incdataset=Topography

Soil suitability for agriculture: Average land quality for cultivation within each pixel. This index is based on the temperature and soil conditions of each grid cell. Source: Ramankutty, N., J.A. Foley, J. Norman, and K. McSweeney. The global distribution of cultivable lands:current patterns and sensitivity to possible climate change. Available at http://nelson.wisc.edu/sage/data-and-models/atlas/data.php?incdataset=Suitability\% 20 for $\% 20$ Agriculture

Water area: Total area covered by rivers or lakes in sq. $\mathrm{km}$ within each pixel. Constructed using the Level 3 of the Global Lakes and Wetlands Database (GLWD) which comprises lakes, reservoirs, rivers, and different wetland types in the form of a global raster map at 30-sec resolution. Source: Lehner, B. and Doell, P. (2004): Development and validation of a global database of lakes, reservoirs and wetlands. Journal of Hydrology 296/1-4: 1-22. Available at http://www.arcgis.com/home/item.html?id= 1ac6777abcc24ab4a9fe39f27c4cb01f

Distance to the sea coast: The geodesic distance (in kilometers) from the centroid of each pixel to the nearest coastline. Constructed using Africa coastline data. Available at http://omap.africanmarineatlas.org/BASE/pages/coastline.htm

Distance to the capital city: The geodesic distance (in kilometers) from the centroid of each pixel to the capital city in the same country. Geographical coordinates for the capital cities were derived from the cShapes dataset. Source: Weidmann, Nils B., Doreen Kuse, and Kristian Skrede Gleditsch. 2010. The Geography of the International System: The CShapes Dataset. International Interactions 36 (1). Available at http://nils.weidmann.ws/projects/cshapes.html

Distance to the national border: The geodesic distance to the nearest national border from the centroid of each pixel. Constructed using the border from the digital chart of the world projection Available at https://worldmap.harvard.edu/data 
Petroleum: Indicator variable that equals one if there is an oil field in the pixel. We use the petroleum Dataset v.1.2 which contains information on all known on-shore oil and gas deposits throughout the world. Source: Lujala, PÃivi; Jan Ketil RÃ,d Nadia Thieme, 2007. "Fighting over Oil: Introducing A New Dataset", Conflict Management and Peace Science 24(3), 239-256. Available at https://www.prio.org/Data/Geographical-and -Resource-Datasets/Petroleum-Dataset/Petroleum-Dataset-v-12/

Diamonds: Indicator variable that equals one if there is a diamond mine in the pixel. We use the Diamonds dataset offers a comprehensive list of all known diamond deposits throughout the world. Source: Gilmore, Elisabeth; Nils Petter Gleditsch, PÃivi Lujala Jan Ketil RÃ,d, 2005. "Conflict Diamonds: A New Dataset", Conflict Management and Peace Science 22(3): 257â292. Available at https://www.prio.org/Data/Geographical -and-Resource-Datasets/Diamond-Resources/ 